\title{
Soğuk Savaş: Amerikan Büyük Stratejisi, Johnson Doktrini ve Kıbrıs
}

\section{The Cold War: American Grand Strategy, Johnson Doctrine and Cyprus}

\author{
Kaan Kutlu ATAÇ* - Mehmet Mert ÇAM ${ }^{* *}$
}

\section{$\ddot{O} z$}

Bu çalışmanın amacı özellikle Başkan Johnson yönetiminin Soğuk Savaş dönemindeki Amerikan Büyük Stratejisi'ni açıklamaktır. Bu çerçevede çalışma üç aşamadan oluşmaktadır: Illk olarak Amerikan Büyük Stratejisi'nin erken Soğuk Savaş'taki kuramsal çerçevesi çizilecektir. İkinci olarak, Büyük Strateji'nin uygulanabilirliğini sağlayan parametreler üzerinde durulacaktır. Bu doğrultuda 1948-1964 arast dönemde, Amerikan Büyük Stratejisi'nin sürdürülebilirliğini sağlayan ve mezkûr kuramı gelişstiren doktrin ve kavram bazlı değişiklikler örneklerle irdelenecektir. Üçüncü aşamada Lyndon B. Johnson dönemindeki "Kıbrıs Sorunu" ve Amerika-Türkiye gerginliği, Büyük Strateji perspektifinde Merkezî Haberalma Teşkilatı'nın Reading Room'unda yer alan evrak üzerinden yorumlanacaktır.

Anahtar Kelimeler: Büyük Strateji, Kütlevi Mukabele, Esnek Karşıllk, Johnson Mektubu, Kıbrıs.

\footnotetext{
* Dr. Öğr. Üyesi, Mersin Üniversitesi, İktisadi ve İdari Bilimler Fakültesi, Uluslararası İlişkiler Anabilim Dal1, ORCID: 0000-0003-3435-9073, e-posta: kaanatac@mersin.edu.tr, kkatac@yahoo.com.

${ }^{* * *}$ Araştırma Görevlisi, Millî Savunma Üniversitesi, Atatürk Stratejik Araştırmalar Enstitüsü (ATASAREN), Uluslararası İlişkiler ve Bölgesel Çalışmalar Anabilim Dalı, ORCID: 00000002-2703-9808, e-posta: mcam3@ msu.edu.tr, mmertcam@hotmail.com.
}

Geliş Tarihi / Submitted: 27.08.2019

Kabul Tarihi / Accepted: 18.08.2020

\section{5}

Güvenlik Stratejileri

Cilt: 16

Sayı: 35 
596

Güvenlik Stratejileri

Cilt: 16

Say1: 35

\section{Abstract}

The aim of this study is to explain and to frame the American Grand Strategy during the Cold War with special emphasis on the Johnson Administration era. Hence the structure of the study is threefold. Firstly, it addresses the theoretical framework of the American Grand Strategy during the Early Cold War. Secondly, it's dwell on the parameters that ensure applicability of the Grand Strategy. Accordingly, in the period between 1948-1964, doctrine and concept-based changes, which evolved and provided continuance of the Grand Strategy, will be analyzed with examples. Thirdly, "Cyprus Question" and the US-Turkey tension during the Johnson Administration are to be expound on the perspective of Grand Strategy from the Central Intelligence Agency documents available on the CIA Reading Room

Keywords: Grand Strategy, Massive Retaliation, Flexible Response, the Johnson Letter, Cyprus.

\section{Giriş}

Savaş dönemi ittifakları kısa süreli olma eğilimindedir. İttifaklar acil ihtiyaçlara cevap olarak ortaya çıkar ve ittifakta yer alan devletler ortak düşmana karşı bir araya gelirler ve aralarındaki husumetler, düşmanın yarattığ 1 tehdit karşısında geçici süre için göz ardı edilir. Tehdit ortadan kalktıktan sonra güç dengelerindeki yeni şekillenmeler dolayısıyla ittifaklar faydası kalmadığı için dağılırlar. ${ }^{1}$ Bu durum 1941 ile 1945 arasında Amerika Birleşik Devletleri (ABD), Sovyet Sosyalist Cumhuriyetler Birliği (SSCB) ve İngiltere arasında oluşturulan "Büyük Savaş İttifakı" için de geçerli olmuştur. Büyük İttifak, ortak düşmana karş1 güçlerin birleştirilmesi ihtiyacı ile oluşturulmuş ve zafere ulaşılmasının

1 “İttifaklar güç yoğunlaşmasına karşılık devletlerin geçici koalisyonları olarak ortaya çıkarlar. Güç dağılımı değiştikçe koalisyonlar da değişir. Düzen, anarşik sistemde kendi güvenliklerini temin etmeyi amaçlayan devletlerin gerekli ve kaçınılmaz sonucu olarak, dengeleyici eylemlerine bağlidır.”, G. John Ikenberry, After Victory: Institutions, Strategic Restrain, and the rebuilding of Order After Major Wars, Princeton University Press, New Jersey, 2001, p. 25. 
ardından hedefin ortadan kalkmasıyla dağılmıştır.

ABD Dışişleri Bakanı Byrnes, Aralık 1945 sonunda üç müttefik ülkenin dışişleri bakanları arasında Moskova' da gerçekleşen konferanstan döndüğü zaman Başkan Truman da kendisiyle görüşmesi için bir not hazırlamıştır. Truman dönemi tarihçisi Messer'in yıllar sonra ortaya çıkardığı bu notta Truman'ın Sovyetler ile ilgili düşüncesinin değiştiğine yönelik çarpıcı ipuçları bulunmaktadır. Zira Truman, Stalin'in Balkanlar, Avrupa ve İran üzerindeki politikalarından iyice rahatsız olmaya başlamıştır. Notta Truman'ın iki devlet arasındaki ilişkinin seyrinin nasıl olacağı net bir şekilde yer almıştır:

"Rusların Türkiye'yi işgal ve Karadeniz Boğazlarından Akdeniz'e kadar bölgeyi ele geçirmeleri niyeti konusunda aklımda hiçbir şüphe kalmadı. Eğer Ruslar demir bir yumruk ve sert dille mukabele görmezse başka bir savaş olacaktır. Yalnızca tek bir dilden anlıyorlar: 'Ne kadar tümeniniz var?' Artık daha fazla tavizkar olmamıza gerek olduğunu düşünmüyorum... Sovyetlere bebek bakıc1lığı yapmaktan yoruldum.",2

Avrupa'nın geleceğinin nasıl şekilleneceğiyle ilgili düzenlenen 1946 Paris Barış Görüşmeleri'nde ABD ve SSCB arasında ciddi görüş̧ ayrılıkları su yüzüne çıktığında savaşın iki büyük gücünün müttefikliği Soğuk Savaş ile birlikte hızla unutulmuştur. Savaşın ABD açısından en önemli sonucu "Monroe Doktrini" çerçevesinde, hasım kuvvet ortadan kalktıktan sonra güvenlikli kalesine çekilmeyi, tıpk1 ilk topyekûn harpte olduğu gibi, 1945-49 arası tecrit temelli bir dış politika izlemesini imkânsız hale getirmesidir. Lakin ABD tecritten farklı bir dış politikaya doğru evrilmesine rağmen savaş halinin zorunlu kıldığı yüksek savunma bütçesi ve daha önce emsali görülmemiş miktarda silah altına alınan insan sayısında hızla bir indirime gitmek zorunda kalmıştır. Savaşın son yılında federal bütçenin \%88'den fazlasını oluşturan savunma

\footnotetext{
${ }^{2}$ Robert H. Ferrell, Off the Record: The Private Papers of Harry S. Truman, Harper \& Row, New York, 1980, p.79-80.
} 
598

Güvenlik Stratejileri

Cilt: 16

Sayı: 35

harcamaları kısıtlanmış, 1945'te 8,2 milyon olan kara kuvvetlerinin mevcudu üç y1l sonra 554 bine indirilmiştir. ${ }^{3}$ ABD'nin konvansiyonel silahlı kuvvetlerinde indirime gitmesinde en önemli etken ABD'nin Eylül 1949'a kadar nükleer silah tekelini elinde tutmasıdır. Byrnes "Amerikan cephaneliğindeki bu harikulade silahın varlığının geçmişe nazaran Rusları daha idare edilebilir" kılacağına inanmaktadır. ${ }^{4}$ Nitekim Atom bombası tekeli Sovyetlerin ABD'ye karşı olan güvenlik bazlı kuşkularının da temelidir. Sovyetlerin Eylül 1949'da ilk atom bombasını denemesi ve ABD'yi vuracak menzile sahip bombardıman uçakları üretmesi "nükleer caydırıcılık" açısından ABD'nin karşısına bir güç olarak çıkmasını sağlamıştır. Öte yandan 24 Haziran 1948 ile 12 Mayıs 1949 tarihleri arasında Sovyetlerin "Berlin Ablukası" da ABD ve müttefikleri için konvansiyonel silahlanma ihtiyacının devam edeceğini göstermiştir. ${ }^{5}$

Washington'un tecrit politikasından vazgeçtiğine dair en önemli gelişme ise 11 Haziran 1948 tarihli "Vandenberg Kararnamesi"dir. ABD'nin karşılaştığı tehditler doğrultusunda tecrit siyasetini terk ederek güvenliğini ilgilendiren ve karşılıklı yardıma dayanan bölgesel ve çok ortaklı anlaşmalara katılabilmesini sağlayan kararın özellikle 2 . ve 3. maddeleri Birleşik Devletler'in küresel ölçekli siyasi, askerî ve teknik yardım yapabilmesinin önünü açmıştır. ${ }^{6}$ Aslında bu kararla birlikte yaşanan paradigma değişikliğine göre, $\mathrm{ABD}$, kendi varoluş nedeni ve

${ }^{3}$ Roger G. Miller, To Save A City, The Berlin Airlift 1948-1949, U.S. Goverment Publishing Office, Washington, 1998, p. 16 ve https://media.defense.gov/ 2010/Oct/01/2001329741/-1/-1/0/AFD-101001-053.pdf (Erişim Tarihi: 18.01.2018)

${ }^{4}$ John Lewis Gaddis, Strategies of Containment: A Critical Appraisal of American National Security Policy during the Cold War, Oxford University Press, Oxford, 2005, p. 17.

5 Ayrıntılı bilgi için bkz. Miller, a.g.e., p. 95-99. Berlin Ablukası'nda Stalin'in tüm tehditlerine rağmen müttefiklerin Batı Berlin'e düzenledikleri tarihin en büyük hava yardım operasyonuna Sovyetlerin ses çıkaramaması, Amerika Dış İşleri Bakanlığı Siyaset Planlama Direktörü George F. Kennan tarafindan Sovyetlerin savaşa gidecek kadar askerî bir tehdit olmadığı yönünde değerlendirilmesine neden olmuştur. Bkz. Foreign Relations of the United States (FRUS), Western Europe, Volume III, 1948, p. 283-285.

${ }^{6}$ A Decade of American Foreign Policy 1941-1949, Vandenberg Resolution, Senate Resolution 239, Eightieth Congress. http://avalon.law.yale.edu/20th_century/ decad040.asp (Erişim Tarihi: 04.01.2018). 
Soğuk Savaş: Amerikan Büyük Stratejisi, Johnson Doktrini ve Kıbrıs

yaşam tarzına karşı tehdit gördüğü komünizme karşı “Amerikan Kalesi” dışında küresel coğrafyada Sovyet yayılmacılığına karşı güvenlik bariyerleri inşa edebilme imkânı kazanmıştır. Birleşik Devletler'in değișen siyasî ve askerî stratejisinin ilk somut örneği dönemin Dışsişleri Bakanlığı Siyaset Planlama Merkezi Başkanı Paul Nitze'nin liderliğinde hazırlanan ve Millî Güvenlik Kurulu'nda kabul edilen 14 Nisan 1950 tarihli NSC 68 belgesidir. Sovyetlerin irredantist politikasını, ekseriyetle George F. Kennan'ın "Çevreleme" kuramı doğrultusunda hem nükleer hem de konvansiyonel harp açısından ele alan NSC 68, Truman'ın istediği tarzda bir kuvvet planlamas1 yapmamasına rağmen, konvansiyonel kuvvetlerin zayıf olmasının, sınırlı bir saldırıya karşı koyma imkânlarını da azaltacağını dile getirmiştir. ${ }^{7}$ Bununla birlikte NSC 68'e göre muhtemel bir Sovyet atom taarruzu da ABD'nin savaşma arzusu ve kabiliyetini kıramasa da topyekûn seferberlik ve silahlanmasına olumsuz etki edecektir. ${ }^{8}$

1 Kasım 1952'de ABD'nin ilk termonükleer bomba hamlesine karş1 12 Ağustos 1953 tarihinde Sovyetlerin kendi termonükleer bombasını başarıyla denemesi "Güç Dengesi" nde yeni bir silahlanma yarışını başlatmıştır. Eisenhower'ın Ocak 1953'te iktidara gelmesi ile birlikte hem nükleer ve konvansiyonel silahlanmayı hem de bu silahlanma ve savunma harcamalarının iktisadî boyutunu içinde barındıracak yeni güvenlik paradigması üzerinde çalışı1mış ve 30 Ekim 1953 'te NSC 162/2 belgesi yayınlanmıştır. ${ }^{10}$ NSC $162 / 2$ 'nin ortaya koyduğu nihai gayeye göre $\mathrm{ABD}$, içinde bulunduğu uzun süreli

\footnotetext{
${ }^{7}$ S. Nelson Drew, NSC-68: Forging The Strategy Of Containment, with Analyses by Paul H. Nitze, National Defence University Press, Washington, 1996, p. 14-15. Belgenin orijinali için bkz. NSC 68, Basic National Security Policy, April 14, Washington, 1950, https://digitalarchive.wilsoncenter.org/document/116191.pdf(Erişim Tarihi: 17.06.2019)

${ }^{8}$ Drew, a.g.e., p. 132-133 ve NSC-68, p. 39-40.

${ }^{9}$ Ali Karaosmanoğlu, "Nükleer Strateji'nin İlk On Yılı", Ankara Üniversitesi Siyasal Bilgiler Fakültesi Dergisi, Cilt 51, Say1 1, 1996, 323-346, s. 335.

${ }^{10}$ Belgenin orijinali için bkz. NSC 162/2, Basic National Security Policy, October 30, Washington, 1953, https://fas.org/irp/offdocs/nsc-hst/nsc-162-2.pdf (Erişim Tarihi: 17.06.2019)
}

\section{9}

Güvenlik Stratejileri

Cilt: 16

Say1: 35 
600

Güvenlik Stratejileri

Cilt: 16

Sayı: 35

"Özgürlük ve Demokrasi" mücadelesinde hem iktisadi açıdan yıpranmamalı hem de etkin bir caydırıcılığa ulaşmalıdır. Bu yaklaşıma "Yeni Bakış" (New Look) adı verilmiştir. Bu yaklaşımda, olası bir sınırlı saldırıda dahi, hasım kütlenin kaynaklarına ve yerleşim merkezlerine taktik nükleer bombalarla taarruz edilerek mukabelede bulunulması hedeflenmiştir. "Yeni Bakış"1n, geliştirdiği bu hibrit savaş modelinde Sovyetler Birliği, Çin Halk Cumhuriyeti ya da diğer bir komünist devletten gelecek saldırıya karşı, Birleşik Devletler, Stratejik Hava Kuvvetleri vasitasıyla hasım kütlenin askerî ve iktisadi sıklet merkezlerine yapılacak bir saldırı ile düşman taarruzunun bertaraf edilmesi öngörülmüştür. Akabinde bölgeye en yakın olan konvansiyonel müttefik orduları ile düşman devleti kontrol altına alınarak onun savaşma azmi kırılacaktır.

NSC 162/2'ye göre Sovyetler Birliği'nin Asya-Pasifik'teki yayılmacılığının Kore Savaşı ile geçici olarak engellenmesine rağmen, Sovyetlerin büyük konvansiyonel askerî gücü, Avrupa'daki uydu devletlerin de desteğiyle Batı Avrupa'yı işgal edebilecek kudrettedir. Batı Avrupa'daki askerî güç ise olası bir Sovyet saldırısını durdurabilecek katma değere sahip değildir. Bununla birlikte ABD'nin taktik nükleer saldırıları dahi Sovyetlerin güçlü hava savunma sistemi ve coğrafi konumundan kaynaklanan hava şartları nedeniyle olası bir işgali durduramayacaktır. ${ }^{11}$ Ayrıca olası bir topyekûn harpte iktisadi maliyetler dışında Birleşik Devletler, Sovyetlerin uydu devletlerine uyguladığı baskı ve psikolojik tedbirlere karşı, Özgür Dünya'nın modus vivendi'sine hem siyasi, iktisadi ve askerî hem de psikolojik unsurlar ile bağlı yerel müttefiklere ihtiyaç duymaktadır. ${ }^{12}$ NSC 162/2'nin diğer bir önemi, ABD periferisinde yer alan ülkelerin "manevi değerleri"ne, moral ve motivasyon unsurlarına ilk kez değinmesidir. ${ }^{13} \mathrm{Bu}$ husus Washington'un müttefiklerini hedef alan Sovyet psikolojik harp mekanizmasına karşı da mücadelede olacağının, başka bir deyişle müttefiklerinin

\footnotetext{
${ }^{11} \mathrm{NSC}-162 / 2$, p. $2-3$.

${ }^{12}$ NSC $162 / 2$, p. 10.

${ }^{13}$ NSC $162 / 2$, p. 17.
} 
Sovyet yanlısı bir politikaya evrilmesine karşı doğrudan ya da dolaylı olarak müdahil olacağının göstergesidir.

Söz konusu belgeye göre Batı Avrupa başta olmak üzere, AsyaPasifik ve Orta Doğu'daki ülkeler Sovyet tehditlerine karşı direnç gösterecek altyapıya sahip değillerdir. Özellikle Güneydoğu Avrupa ve Orta Doğu, Kennan'ın Sovyetler Birliği’ni çevreleme kuramına göre Sovyetlere doğrudan sınırı olması nedeniyle hasım lehine boşluk bırakılmaması gereken bir coğrafyadır. Bu yüzden $\mathrm{ABD}$ :

“Orta Doğu'da Sovyet irredantizmine karşı güçlü bölgesel alanlar oluşturmak zorundadır. Bu doğrultuda ABD; Türkiye, Pakistan ve imkân olursa İran'da istikrarı yakalamak için bu ülkelere siyasi ve askerî alanlarda destek vermeli ve ekonomik, teknik alanlarda yardım etmelidir." ${ }^{14}$

1956'da sonbaharında başlayan Süveyş Krizi ve Arap-İsrail çatışmaları neticesinde Soğuk Savaş'ın Orta Doğu'da şiddetini arttırmasıyla 162/2'nin bu coğrafyada tatbikini sağlayacak Eisenhower Doktrini 5 Ocak 1957'de ilan edilmiştir. Fakat Ekim 1956'da Sovyetlerin Macaristan'1 işgali, müteakiben Ekim 1957'de Sovyetlerin Sputnik ile uzaya ilk uydu firlatan ülke olması ve başta Orta-Latin Amerika ve Asya-Pasifik olmak üzere "Üçüncü Dünya"da komünist ayrılıkçı ve gerilla hareketlerine desteği Eisenhower Doktrini'nin uygulama alanını genişlettirmiştir. Artı sadece Orta Doğu'da değil uluslararası komünizmin güç odağı olmaya çalıştı̆̆ tüm coğrafyalarda "yerel güçlerin" desteğiyle birlikte uygulanması kararlaştırılmıştır.

Eisenhower'n halefi Kennedy ve kurmayları ise ilk etapta uluslararası komünizme karşı mücadelenin önceki döneme göre biçim olarak daha enerjik, yumuşak başlı ve özel (örtülü) olmasını savunmalarına rağmen, ${ }^{15}$ stratejik kavram açısından NSC 162/2'ye sadık kalmışlardır. Bu husus John F. Kennedy tarafından 5 Ocak 1961 tarihli

\footnotetext{
${ }^{14}$ NSC 162/2, p. 21.

15 "Kennedy's Foreign Policy", /https:/history.state.gov/departmenthistory/shorthistory/jfk-foreignpolicy (Erişim Tarihi: 15.01.2019)
}

\section{1}

Güvenlik Stratejileri

Cilt: 16

Say1: 35 
602

Güvenlik Stratejileri

Cilt: 16

Sayı: 35

Başkanlık devir törenindeki konuşmasında da açıkça ifade edilmiştir:

“... İyiliğimizi ya da kötülüğümüzü isteyen tüm uluslar şunu mutlaka bilmelidir; özgürlüğümüzü korumak ve varlığımızı sürdürmek, düşmanlarımıza karşı koymak ve dostlarımızı desteklemek için, her türlü fedakârlığı yapmaya, her yükün altına girmeye, her zorluğa göğüs germeye ve her bedeli ödemeye hazırız." 16

Yine Kennedy'nin 5 Mayıs 1961'de Kongre'de yaptığı konuşmada izah ettiği “Özgürlük Doktrini”, ABD'nin izleyeceği stratejiyi açık bir şekilde ortaya koymaktadır:

“...Özgürlüğe düşman olanın dışında hiçbir insana -ya da herhangi bir millete- ya da herhangi bir sisteme karşı değiliz... Ayrica burada herhangi bir ismi taşıyan veya herhangi bir alana yönelik yeni bir askerî doktrin sunmak için gelmiyorum. Özgürlük doktrinini tanıtmak için buradayım... Günümüzde özgürlüğün savunulması ve yaygınlaştırılması için cereyan eden büyük savaşın alanı, dünyanın yükselen halklarının toprakları olan Asya, Latin Amerika, Afrika ve Orta Doğu'dur. Devrimleri insanlık tarihinin en büyüğüdür. Onlar adaletsizlik, zulüm ve sömürüye bir son vermek istiyorlar... Özgürlük düşmanları ne devrimi ne de onu zorlayan koşulları yarattılar. Ama arkalarından esen rüzgârla onları ele geçirmek istiyorlar. En önemlisi bunu aşikâre biçimden ziyade gizli yapıyorlar... Her sorunlu bölgeye silah, provokatör, uzman ve propagandalarını gönderiyorlar. Geçtiğimiz on iki ayda Vietnam'da sadece 4000 bin devlet görevlisi gerilla ve suikastçılar tarafından katledildi... Bu müthiş silahlarla, özgürlük düşmanları topraklarını pekiştirmeyi-sömürmeyi, kontrol etmeyi ve nihayet dünyanın en yeni uluslarının umutlarını yok etmeyi planliyor ve bu on yılın bitiminden

16“'Inaugural Address, 20 January 1961”, https://www.jfklibrary.org/learn/aboutjfk/historic-speeches/inaugural-address (Erişim Tarihi: 16.01.2019). 
Soğuk Savaş: Amerikan Büyük Stratejisi, Johnson Doktrini ve Kıbrıs

önce bunu yapma ihtiraslarına sahipler. Bu bir irade ve gayenin yanı sıra güç ve şiddetin mücadelesidir- zihin ve ruhlar ile yaşamlar ve bölgeler için bir savaş. Ve bu mücadelede, bir yana duramayı.."17

Konuşmadan anlaşılacă̆ı üzere Kennedy, uluslararası komünizmin ya da kendi deyimiyle özgürlük düşmanlarının Üçüncü Dünya’ya yönelik örtülü faaliyetleri neticesiyle ilerlediklerini, bu duruma Birleşik Devletler'in kayıtsız kalamayacağını belirtmiştir.

17 Nisan 1961'de Küba'daki komünist Castro yönetimine karş1 başarısız Domuzlar Körfezi Çıkarması'ndan sonra 1962'nin ilk yarısında Vietkonglara karşı eğit-donat kapsamında 16 bin askerin Güney Vietnam'a gönderilmesi, Latin Amerika'daki ülkelere "Peace Corps" altında iktisadî yardım hareketi ve nihayet ABD'nin Türkiye ve İtalya'ya, Sovyetlerin de Küba'ya yerleştirdiği orta menzilli balistik füzelerin yarattığı Küba Füze Krizi, yukarıdaki doktrin kapsamında ele alındığında Eisenhower Doktrini'ndeki Yeni Bakış stratejisindeki nükleer tandanslı, katı dış politikanın terk edildiğini göstermektedir. Zira bunun yerine "Esnek Karşıllk" stratejisi doğrultusunda daha geniş bir yaptırım sahasında harekât kabiliyeti arttırılmış, Küba Krizi’nde olduğu hasım kuvvetin siyasi manevralarına taktik seviyede geri adım atarak dahi cevap verilebilen bir doktrin geliştirilmiştir. Bu durum, "Çevreleme" kuramının NSC 68'de fazla antagonist olduğundan şikâyet eden Kennan'ın "Uzun Telgraf”ta kastettiği Sovyetlerle mücadelede benimsenecek yol haritasına da daha uygundur. ${ }^{18}$

\footnotetext{
17 "President Kennedy's Special Message To The Congress On Urgent National Needs, 25 May 1961", https:/www.jfklibrary.org/archives/other-resources/john-f-kennedyspeeches/united-states-congress-special-message-19610525 (Erişim Tarihi: 16.01.2019).

${ }^{18}$ Leanne M. J. Bacon, George F. Kennan's Strategy of Containment: An Assessment of Kennan's Coherence and Consistency, Department of American and Canadian Studies, Birmingham Üniversitesi, Birmingham, 2010, p. 63-65. (Yayımlanmamış Felsefe Yüksek Lisans Tezi). Kennan'ın NSC 68 hakkındaki görüşleri için bkz. John Lewis Gaddis, George F. Kennan, An American Life, The Penguin Press, New York, 2011, p. 391-392.
}

\section{3}

Güvenlik Stratejileri

Cilt: 16

Say1: 35 


\section{4}

Güvenlik Stratejileri

Cilt: 16

Sayı: 35

\section{Amerikan Büyük Stratejisi ve Johnson Doktrini}

Yukarıda ifade edildiği üzere, Birleşik Devletler'in İkinci Dünya Savaş1 sonrasında kurulacak yeni dünya düzeninde başta kendi güvenliği olmak üzere dünya barışını da sağlayacak "Grand Strategy"e (Büyük Strateji) ihtiyacı hâsıl olmuştur. Bu büyük stratejinin sürdürülebilir olması, hasımlarının savaşma kabiliyetini ve bunu istinat ettiği manevi kuvvetleri, bağlı oldukları ideolojik yapı ve soyut gerekçeleri etkisiz hale getirmek suretiyle kesin olarak mağlubiyetini sağlayana kadar devam etmelidir. $\mathrm{Bu}$ büyük stratejinin diğer bir özelliği, Birleşik Devletler ve müttefiklerinin halklarını, nihai hedefe ulaşana dek tüm millî güç unsurlarının mezkûr hedef doğrultusunda kullanılacağına dair onları ikna edebilecek olmasıdır. $\mathrm{Bu}$ anlayış tüm farklılıkları ortadan kaldırmalı ve o hedef doğrultusunda kütleleri Hobbesçu bir korku/güvenlik ekseninde bir araya getirmelidir. ${ }^{19}$

ABD’nin Soğuk Savaş'taki Büyük Stratejisi'nin manevi alt yapısı, "Amerikan Yaşam Tarzı" (The Way of American Life) ve "Hür Dünya" (Free World) metaforlarıdır. ${ }^{20} \mathrm{Bu}$ manevi yapılanma (Rearmament) nihai hedefe giden yolda hasım kuvvet ile hiçbir şart ve ahvalde pazarlık konusu ya da esnetilebilir olmayacak, zaman mefhumundan bağımsız olacaktır. Ayrıca yaşam tarzı kaygısı, hasım kütlenin imha, ifna ya da etkisiz hale getirilene dek mücadeleye istinat edilen manevi unsuru olacaktır. 1945-1991 yılları arasındaki Soğuk Savaş sürecinde taraflar arasında doktriner düzlemde değişmeler olmasına rağmen, Hür Dünya retoriği "zafer" elde edilene dek Birleşik Devletler tarafından kullanılmıştır. $^{21}$

19 “George Kennan's 'Long Telegram', 22 February 1946”, https://digitalarchive. wilsoncenter.org/document/116178.pdf (Erişim Tarihi: 19.01.2019)

20 Amerikan Yaşam Tarzı'nın temelini Truman'ın 12 Mart 1947'deki meclis konuşmasında ifade ettiği "Batı Medeniyeti", "Demokrasi" ve "Hristiyanlık" paradigmaları oluşturmaktadır. Truman Doktrini için bkz. "President Truman's Special message to the Congress on Greece and Turkey: The Truman Doctrine, 12 March 1947", https://www.trumanlibrary.gov/soundrecording-records/sr64-47-president-trumansspecial-message-congress-greece-and-turkey-truman (Erişim Tarihi: 19.01.2019)

${ }^{21}$ Ayrıntılı bilgi için bkz. R.D. Hooker, The Grand Strategy of the United States, INSS Strategic Monograph, Institute for National Strategic Studies, National Defense 
Soğuk Savaş: Amerikan Büyük Stratejisi, Johnson Doktrini ve Kıbrıs

Büyük Strateji'nin maddi dayanağı ise 22 Şubat 1946'de yukarıda ifade edilen Kennan'ın Uzun Telgraf'ındaki Sovyetleri çevreleme kuramı olmuştur. Teorinin nüvesi itibarıla, Sovyetler Birliği, İkinci Dünya Harbi'nin başlarında Spykman'ın geliştirdiği Kenar Kuşak Teorisi'ne göre çevrelenmelidir. Bu doğrultuda Sovyetler Birliği, Spykman'ın İç Hilal olarak adlandırdığı; Avrasya'yı Büyük Avrupa Ovası'ndan, Balkanlar'a ve oradan Çin ve Doğu Sibirya'ya kadar çevreleyen kuşağın kontrolü ile baskı altına alınacaktır. ${ }^{22}$ Kalpgâh'a yani Sovyetler Birliği'ne uygulanan bu coğrafi baskı, Slav dillerine hâkim iyi bir Sovyetolog olan Kennan'a göre üç ana prensip üzerinde şekillenmelidir.

İlk olarak Sovyetlere karşı izlenecek siyaset uzun vadeli planlanmalıdır. Zira çoğunlukla muhafazakâr ve milliyetçi olan Ruslar, Sovyet psikolojik harekâtları ile birlikte her şart ve ahvalde liderlerinin peşlerinden gideceklerdir. Bu yüzden çevreleme kuramının sürdürülebilir bir yapı ve teşkilatlanmaya ihtiyacı bulunmaktadır. İkincisi Amerikan tarafi açısından moral ve motivasyon unsuru sabır olmalıdır. Rusların uzun vadeli ve sabırlı bir direniş karşısında çözüldükleri tarihî örneklerle ispatlanmışır. Başka bir deyişle tepe noktada kırmızı çizgilerle belirlenmiş bir ülkü karşısında Ruslar, er ya da geç mağlup edileceklerdir. Son olarak iki yüzlü ve güvenilmez Rus dış politikasının manevralarına karşı gelebilmek ve "oyuna gelmemek" için doktriner düzeyde esnek bir taktik belirlenmelidir. ${ }^{23}$

Büyük stratejiler geleneksel olarak savaşların planlanması ve yürütülmesiyle alakalıdır. Gaddis' in tanımıyla büyük strateji "potansiyel olarak sınırsız arzuların zorunlu olarak sınırlı imkânlarla bir araya

University, National Defence University Press, Washington, 2014, p. 21-24.

${ }^{22}$ Nicholas John Spykman, The Geography of the Peace, Harcourt, Brace and Company, San Diego, 1944, s. 24-28.

${ }^{23}$ Kennan'ın ' $\mathrm{X}$ ' müstear ismiyle Foreign Affairs'de çıkan "Sovyet Yönetiminin Temeli" adlı makalesi için bkz. "The Sources of Soviet Conduct by "X" (George F. Kennan) July 1947”, https://www.foreignaffairs.com/articles/russian-federation/1947-07-01/ sources-soviet-conduct (Erişim Tarihi: 15.02.2019) 
606

Güvenlik Stratejileri

Cilt: 16

Sayı: 35

getirilmesi"dir. ${ }^{24}$ Büyük stratejide ön plana çıkartılan unsurlar, hedefe ilerleme konusunda azimli olma ve hedefe ulaşma noktasında pusulaya sahip olma ile neyin tehlike altında olduğuyla ilgilidir. Bu doğrultuda hedefin net olarak belirlenmesi, ona ulaşmada izlenecek güzergâhın çizilmesi ve uygulamada çevrenin dayatabileceği değişikliklere uyum sağlama yeteneği Soğuk Savaş’ta Birleşik Devletler'in büyük stratejisinde de öne çıkan unsurlardır. Birleşik Devletler açısından devletin devamı ve varlığının korunmasıyla eş anlamlı olan Amerikan hayat tarzı tehdit altındadır. Bu tehdidin nasıl bertaraf edileceği ile ilgili oluşturulacak yapılacaklar listesi karar alıcılar ve uygulayıcılar açısından kutup yıldızını oluşturacaktır. Martel'e göre de, "Soğuk Savaş sıklıkla Amerikan büyük stratejisinin teşkil edilmesinde en yüksek standardın örneği olarak kullanılır."25 1945-1991 y1lları arasında ABD'nin SSCB'ye karşı izlediği politikaları göz önüne alındığında Kennan'ın tavsiyelerinin genel hatlarıyla korunduğunu söylemek mümkündür. Nitekim 1991 sonunda Sovyetler Birliği dağıldığında Kennan'ın öngörüsü ispatlanmış ve Sovyetlerin coğrafi, siyasi ve ekonomik alanlarda gelişimi engellenmiştir. ${ }^{26}$ Hedef elde edilene kadar varlığını koruyan ve taviz vermeyen büyük strateji, maddi ve manevi boyutlarıyla kendini muhafaza etmiştir. Lakin doktriner düzeyde yukarıda izah etmeye çalıştığımız üzere Eisenhower ve Kennedy dönemlerinde gibi konsept değişikliğine gidilmiştir.

Eisenhower'ın Yeni Bakış stratejisinde Kütlevi Mukabele konsepti, askerî zeminde meydana gelen etkide güç artışı, menzildeki alan

${ }^{24}$ John Lewis Gaddis, On Grand Strategy, Penguin Press, New York, 2018, p. 22.

${ }^{25}$ William C. Martel, Grand Strategy In Theory And Practice: The Need For An Effective American Foreign Policy, Cambridge University Press, New York, 2015, p. 244.

${ }^{26}$ Dönemin Sovyet lideri Mihail Gorbaçov 25 Aralık 1991'de SSCB liderliğinden istifa etmesinden birkaç saat önce Bush'u telefonla aramış ve Başkana nükleer silahların yetkisinin Rusya Federasyonu Başkanı Yeltsin'e devredileceğini, huzurlu bir Noel akşamı geçirebileceğini ifade etmişti. "Memorandum of Telephone Conversation, Gorbachev-Bush, 25 December 1991, Last phone call", https://nsarchive.gwu.edu/ dc.html?doc=3247156-4-Memorandum-of-Telephone-Conversation-Gorbachev

(Erişim Tarihi: 20.01.2019) 
Soğuk Savaş: Amerikan Büyük Stratejisi, Johnson Doktrini ve Kıbrıs

genişliği ve platform çeşitliliğindeki esneklik Kennedy döneminde "Esnek Karş1lık" konseptine (Flexible Response) evrilmiştir. ${ }^{27}$ Nitekim NSC 68'ye ilham veren ve NSC 162/2'de evrimleşen "Çevreleme" kuramından taviz verilmemiştir. Vaka üzerinden değerlendirdiğimizde ise 1954 y1lında nükleer doktrin kapsamında inşa edilen İncirlik Üssü'nün açılmasıyla 1962 yılında Güney Vietnam'a "eğit-donat" kapsamında gönderilen 16 bin Amerikan askerin ya da TPAJAX Operasyonu ile Latin Amerika'daki ülkelere "Peace Corps" altında iktisadî yardım hamlesi arasında "Büyük Strateji" nazarında hiçbir fark yoktur. Başka bir deyişle uygulamada çevreleme ile ifade bulan büyük strateji, doktriner anlamda küçük değişikliklere uğramış olmasına rağmen yedi Amerikan başkanın yönetimi altında dikkat çekici bir şekilde istikrarını korumuştur. ${ }^{28} \mathrm{Bu}$ noktada Büyük Strateji'nin bulunduğu konumu ve Amerikan Büyük Stratejisi'ni bir şema ile şöyle ifade etmek mümkündür:

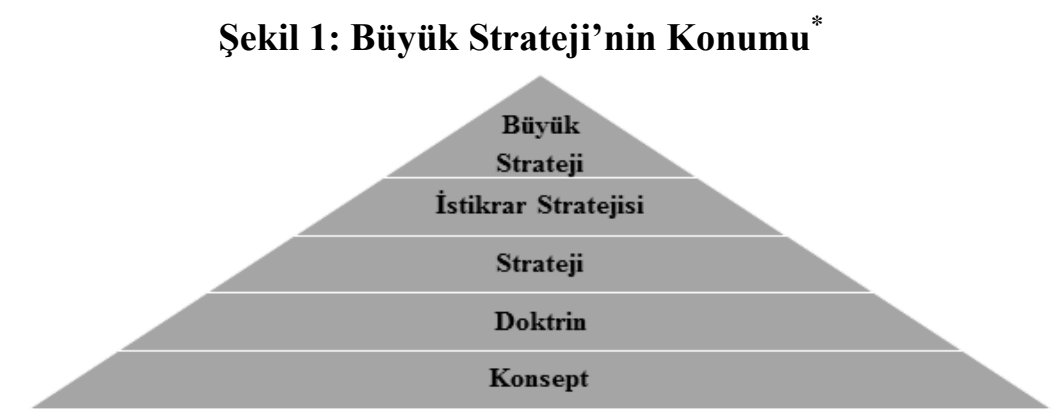

\footnotetext{
${ }^{27}$ Jane E. Stromseth, The Origins of Flexible Response: Nato's Debate over Strategy in the 1960s, Palgrave Macmillan, Basingstoke. 1988, s. 122-126.

${ }^{28}$ Martel, a.g.e., p. 244, Soğuk Savaş'ta Başkanlar nezdindeki uygulamalar için bkz. p. 248-299.

Şekil yazarlar tarafindan oluşturulmuştur.
}

\section{7}

Güvenlik Stratejileri

Cilt: 16

Say1: 35 
608

Güvenlik

Stratejileri

Cilt: 16

Sayı: 35

\section{Şekil 2: Amerikan Büyük Stratejisi ve Unsurları **}

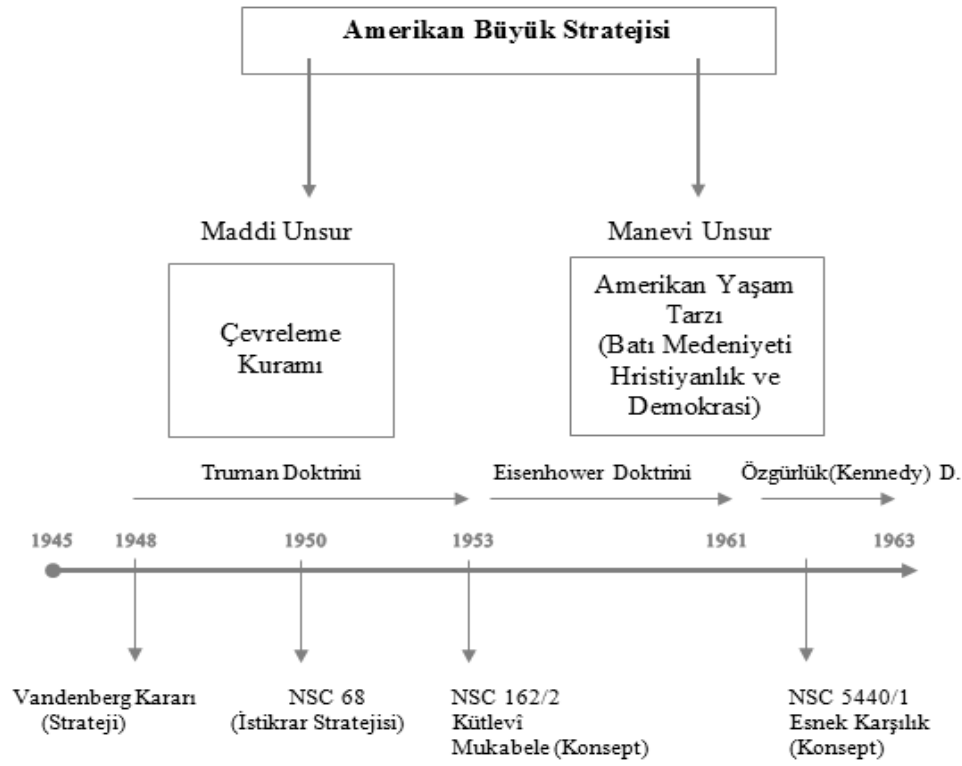

\subsection{Lyndon B. Johnson ve Doktrini}

22 Kasım 1963'te Kennedy'nin bir suikast sonucu öldürülmesinden sonra başkan olan Johnson 1908'de Teksas yakınlarındaki Johnson City'de beş çocuklu bir ailenin ilk çocuğu olarak dünyaya gelmiştir. Johnson, ögretmenlik eğitiminden sonra 1934'te babas1 Sam Ealy Johnson gibi Teksas'tan Temsilciler Meclisi'ne üye seçilmiş, 1935 yılında Johnson'ın da siyasi kahramanı olan dönemin Başkan Yardımcısı Franklin Roosevelt' in "New Deal" kapsamında gençlerin Büyük Buhran sırasında iş bulmalarına veya gönüllü çalışmalarına olanak sağlayan Ulusal Gençlik İdaresi'nin Teksas yetkilisi olmuştur. 1941'deki Senato

*** Şekil yazarlar tarafindan oluşturulmuştur. 
Soğuk Savaş: Amerikan Büyük Stratejisi, Johnson Doktrini ve Kıbrıs

seçimindeki başarısızlığına rağmen beş kez Temsilciler Meclisi'ne seçilen Johnson, gönüllü olarak askere giden ilk Kongre üyesi olmuş ve Amerikan Deniz Kuvvetleri'nde teğmen rütbesinde Güney Pasifik'te görev almıştır. Kongre üyelerinin Washington'a çağrıldığ 1942 yazına kadar Pasifik'te kalmış ve hizmetlerinden dolayı "Silver Star" madalyası ile ödüllendirilmiştir. ${ }^{29}$

1948'de Teksas'tan Senato'ya seçilen Johnson, 1953’te Senato'nun en genç azınlık lideri, ertesi yıl Demokratların kontrolü ele geçirmesi ile en genç "Çoğunluk Lideri" olmuştur. Cumhuriyetçi Başkan Eisenhower ile yapıcı iş birliği, ekseriyetle önemli yasa teklifleri hususunda partisini yönlendirmesi nedeniyle Washington'da güçlü bir figür haline gelmiştir. 1960'taki Başkanlık seçimlerinde özellikle güneydeki Demokratlar arasında nüfuz sahibi olan Johnson, Kennedy'nin Cumhuriyetçi Richard Nixon'a karşı seçimi kazanmasında etkili olmasına rağmen, Beyaz Saray'da Başkan yardımcılığı sırasında arka planda kalmıştır. ${ }^{30}$

Başkan olduktan sonra iç politikada Kennedy'nin "özgürleştirici” mirasını devralan Johnson, 1964 'te özellikle Afro-Amerikalılara yönelik reform programı başlatmıştır. 2 Temmuz 1964'te imzaladığı Medeni Haklar Yasası ile siyahilere kamusal alanda uygulanan negatif ayrımcılık yasaklanmış, 1965'te imzalanan Seçim Hakları Yasası'na göre Afro-Amerikanlara seçilme hakkı tanınmıştır. 1966 yılında Edward Brooke, Massachusetts'den senatör seçilerek, İç Savaş'tan sonraki Restorasyon Dönemi'nden bu yana Senato'ya giren ilk siyah olmuştur. Ertesi y1l ise Johnson, Thurgood Marshall'1 Yüksek Mahkeme'nin ilk siyahi üyesi olarak atamıştır. ${ }^{31}$

\footnotetext{
${ }^{29}$ Robert A. Caro, The Path to Power, The Years of Lyndon Johnson, Volume 1, Vintage, New York, 1990, p. 531.

30 "LBJ: Biography", http://www.lbjlibrary.org/lyndon-baines-johnson/lbj-biography/ (Erişim Tarihi: 20.01.2019)

31 "Lyndon B. Johnson", https://www.whitehouse.gov/about-the-white-house/ presidents/lyndon-b-johnson/ (Erişim Tarihi: 20.01.2019)
}

\section{9}

Güvenlik Stratejileri

Cilt: 16

Say1: 35 
610

Güvenlik Stratejileri

Cilt: 16

Sayı: 35

Johnson'in sosyal devlet paradigması doğrultusunda ortaya attı̆̆ "Great Society" slogan1, herkesin eşit siyasi ve sosyal haklara sahip, yoksulluktan arınmış ve yeterli sağlık koşullarına ulaşabildiği bir refah toplumu yaratmayı amaçlamıştır. Bu doğrultuda 1964 yılında imzaladığı İktisadi Fırsat Yasası ile "Yoksulluğa Karşı Savaş" programı, eğitim ve iş alanlarında firsat eşitliği sunmaktadır. "Head Start" ve "Job Corps" gibi kurumlar vasıtasıyla gençlere iş bulma programları hayata geçirilmiş, işsizlere iş eğitimi verilmiş ve iş bulmaları sağlanmıştır. Johnson; asgari ücretin yükseltilmesi, ihtiyaç sahiplerine gıda yardımı ve yoksul öğrencilere devlet yardımı gibi yapıcı tedbirlerin dışında "Medicare" adı verilen 65 yaş üstü yurttaşlara, engellilere ve ihtiyaç sahiplerine ücretsiz sağlık hizmeti sağlayan bir sigorta sistemi kurmuştur. ${ }^{32}$

Kasım 1964 başkanlık seçimlerinden önce atılan bu adımlar, seçimlerde Johnson'un \%61 gibi daha önce görülmemiş bir oy oranıyla seçimleri kazanmasını sağlamıştır. Johnson'ın başkanlık döneminin sona erdiği Kasım 1968'a kadar reform hamleleri, çevreyi koruma, hayvan hakları, bireysel silahlanmanın azaltılmasına yönelik tedbirler ya da yerlilere karşı uygulanan ayrımcılığa karşı 11 Nisan 1968'de imzaladığı Medeni Haklar Yasası gibi hamleler Vietnam Savaşı'ndaki kayıplar nedeniyle Amerikan kamuoyu nazarında hak ettiği karşılığı görememiştir. ${ }^{33} \mathrm{Bu}$ hususta ayrıntılarına aşağıda değinilen Johnson Doktrini'nin müdahaleci diş politika stratejisinin etkisi büyüktür. Gaddis, Johnson'ın görünürde sınırsız kaynaklarla Amerika'nın aynı anda hem "silahlar" hem de "tereyağı"na sahip olabileceği algısına sahip olduğunu belirtmektedir. Bu alg1 sayesinde Johnson ayn1 anda daha önce emsali görülmemiş bir maliyette bir savaş ve maliyetli bir reform program siyaseti izlemiştir. ${ }^{34}$ Johnson bu noktada büyük stratejinin en önemli kıstası olan amaçlar ve araçlar arasındaki dengenin sağlanmasında kısıtlı kaynakların nasıl kullanılacağıyla ilgili tipik

32 Joshua Zeitz, Building the Great Society: Inside Lyndon Johnson's White House, Penguin Books, New York, 2018, p. 146-147.

${ }^{33}$ Zeitz, a.g.e., p. 178-179.

${ }^{34}$ Gaddis, a.g.e., p. 270. 
Soğuk Savaş: Amerikan Büyük Stratejisi, Johnson Doktrini ve Kıbrıs

siyasi tercih sıkıntısını yaşamaktadır.

Başkan Eisenhower'ın 1953-1959 yılları arasında Dışişleri Bakanlığını yürüten John Foster Dulles'ın, Latin Amerika'ya yönelik politika oluşturulmasında belirlediği cebri konsept, Kennedy'nin başkanlığının başında Latin Amerika'yı, "dünyanın en tehlikeli bölgesi" ilan etmesiyle birlikte devam etmiştir. ${ }^{35}$ Özellikle 1960'ların başında Latin Amerika'da başlayan komünist hareketler, Birleşik Devletler'in Monroe Doktrini'nden beri “Arka Bahçesi” olarak gördüğü bu bölgede uluslararası komünizme karşı sert ve önleyici tedbirler almasına yol açmıştır. Bununla birlikte "Domuzlar Körfezi Hadisesi"nin Sovyetlerin psikolojik harp mekanizmasına kazandırdığı pozitif durumun etkisiz hale getirilmesi gereklidir. Aksi takdirde Küba'daki rejim değişikliğinin bölgedeki diğer coğrafyalarda "Domino Etkisi" yaratması kaçınılmaz olarak değerlendirilmiştir.

1962'deki Dominik Cumhuriyeti'nde iktidara gelen Dominik Devrimci Partisi ve anti-Amerikanci lideri Juan Bosch, Eylül 1963'te asker güdümlü bir hükümet darbesi ile görevden uzaklaştırılmasından sonra Dominik Cumhuriyeti'nin "kırılgan/düşkün devlet” konumuna düşmesi ve 1965 başında Bosch yanlısı radikal grupların Donald Reid Cabral hükümetine karşı "stratejik saldırı"ya geçmeleri üzerine Amerika Birleşik Devletleri, 28 Nisan 1965'te adaya müdahale etmiştir. ${ }^{36} 2$ Mayıs 1965 'te Johnson, Dominik Cumhuriyeti'ne yönelik müdahale ile ilgili yaptığı konuşmasında yeni doktrinini geçmişe yaptığı referanslarla açıklamıştır:

“... Ulusların işlerinde, büyük ilkelerin çatışma ve tehlike sıkıntısı içinde sınandığı zamanlar vardır. Amerikan ulusları için (bugün) böyle bir zaman... Bay Bosch'un geri dönüşüne karş1 çıkanlar, ülkeyi kontrol altına almak için bir askerî komite

\footnotetext{
${ }^{35}$ Stephen G. Rabe, The Most Dangerous Area in the World: John F. Kennedy Confronts Communist Revolution in Latin America, The University of North Carolina Press, North Carolina,1988, p. 79-81.

36 "FRUS, 1964-1968, Volume XXXII, Dominican Republic; Cuba; Haiti; Guyana" https:/20012009.state.gov/r/pa/ho/frus/johnsonlb/xxxii/44733.htm (Erişim Tarihi: 17.01.2019)
}

\section{1}

Güvenlik Stratejileri

Cilt: 16

Say1: 35 
612

Güvenlik Stratejileri

Cilt: 16

Say1: 35

oluşturdular. Diğerleri sokağa çıktılar ve Cumhurbaşkanı Bosch adına bir isyana önderlik etmeye başladılar. Kontrolü sağlayan etkili merkezî hükümet ise çatışma ve karmaşayı engelledi. Bu arada, devrimci hareket trajik bir hale döndü. Birçoğu Küba'da yetişen komünist liderler, kargaşadan yararlanarak bölgeyi kendilerine bir tutunma noktası olarak gördüler ve devrime katıldılar ve aslında demokrasiye ve sosyal adalete bağlı olan bu devrimci hareket kısa bir süre içinde komünist komplocuların eline geçti... Amerikan ulusları Batı Yarımküre'de diğer bir komünist hükümetin iktidarı ele geçirmesini izin vermemelidir ve asla izin vermeyecektir. Zira Ocak 1962'de deklare ettikleri üzere komünizmin ilkeleri Amerikanlar arasındaki sistemin ilkeleriyle asla bağdaşmamaktadır...

Sevgili Başkanımız John F. Kennedy'nin, ölümünden bir haftadan daha az bir zaman önce bize şunları söyledi: ' $\mathrm{Bu}$ yarımkürede, başka bir Küba'nın kurulmasını önlemek için emrimizdeki her kaynağ 1 da kullanmalıyız.' Bu (paradigma) ve bu yarımkürenin demokratik güçlerinin ortak eylem ve ortak amacı olacak. Çünkü tehlike aynı zamanda ortak bir tehlikedir ve ilkeler ortak ilkelerdir.

Simon Bolivar, sürgünde iken şunları yazmıştı: 'Peçe parçalandı. Işıkları çoktan gördük. Bu yüzden karanlığa bir daha dönmek üzere bir emelimiz yok.'

Ulusumuzu, sadece Amerika Birleşik Devletleri'ni değil, bu yarımkürenin her özgür ülkesini de yok etmek isteyenlere karşı savunacağız. Daha önce de söylediğim gibi kimseyi gömmek istemiyoruz. Ancak gömülmeye de niyetimiz yok." ${ }^{37}$

Johnson'ın konuşmasından açıkça anlaşılacağı üzere, Batı Yarımküre'de komünist bir rejime karşı askerî müdahaleler dâhil tüm

37 "Lyndon Johnson, Published Text of Speech on the Domincan Republic Intervention, 2 May1965”, (The Johnson Doctrine Speech), https://loveman.sdsu.edu/ docs/1965JohnsonDoctrine.pdf (Erişim Tarihi: 20.01.2019). 
Soğuk Savaş: Amerikan Büyük Stratejisi, Johnson Doktrini ve Kıbrıs

seçenekler ihtimal dâhilindedir. Metinde görüldüğü üzere "Hür Dünya" metaforu defaten vurgulanmış, fakat bir makro milliyetçilik örneği olarak sadece ABD değil, iki kıtada yaşayan tüm Amerikanlar savunulacak bir unsur olarak zikredilmiştir. $\mathrm{Bu}$ durumun sahadaki uygulaması Dominik müdahalesinde görülmektedir. Amerikan Deniz Piyadeleri'nin 28 Nisan 1965'te adaya çıkmasından sonra, 29 Nisan'da Amerikan Devletleri Örgütü (OAS) taraflara ateşkes çağrısı yapmış ve ardından "Inter Amerikan Barış Gücü”nün kurulmasına karar vermiştir. 26 Haziran 1965 tarihi itibarıyla oluşturulan barış gücünde, ABD’ye ait 12400 askerin yanı sira, Brezilya, Honduras, Paraguay, Nikaragua, Kosta Rika ve El Salvador'a ait 1700 asker görev almıştır. ${ }^{38}$

$\mathrm{Bu}$ tarihlere paralel olarak Vietnam Savaşı'nda Amerikan stratejisi değişmektedir. 2 ve 4 Ağustos 1964 tarihlerinde Tonkin Körfezi'nde USS Maddox zırhlısına yönelik taciz atışları sonrasında 10 Ağustos'ta Kongre, Tonkin Körfezi Kararnamesini kabul etmiş ve Johnson'a Kuzey Vietnam'a doğrudan müdahale yetkisi vermiştir. Johnson, Vietnam'daki mevcut yaklaşımı korumak, savaşın şiddetini arttırarak Kuzey Vietnam'1 vurmak tercihlerinin dışında “yükseltilmiş bir tercih"in (graduated response) peşinden gitmiş ve Amerikan kuvvetlerinin Saygon'daki moralini güçlendirmek, Güney Vietnam'daki Vietkong'a saldırmak ve Hanoi'nin komünist ayaklanmasına yardımını kesmek üzere 14 Aralık'ta Laos'taki tedarik hatlarının bombalanmasıyla "Barrel Roll Operasyonu”nu başlatmıştır. ${ }^{39} 24$ Aralık 1964'te Güney Vietnam'da Amerikan Ordusu mensuplarının kaldığı Bricks Oteli’nin bombalanmasından sonra Johnson ihtiyatlı davranarak kara müdahalesinden kaçınmasına rağmen 8 Mart 1965 'te 3500 mevcutlu Amerikan Deniz Piyadeleri Vietnam'a çıkmıştır. Amerikan kamuoyunun baskısına ve Savunma Bakanı McNamara'nın ihtilafına rağmen

\footnotetext{
${ }^{38}$ Ayrıntılı bilgi için bkz. "Inter-American Peace Force, Public Affairs Office, Santo Domingo, Dominican Republic, 1966", https://history.army.mil/html/bookshelves/ resmat/dom_republic/IAPF_Stability_Ops_Rpt.pdf(Erişim Tarihi: 19.01.2019)

39 "Lyndon B. Johnson and The Vietnam War", https://prde.upress.virginia.edu/ content/Vietnam (Erişim Tarihi: 19.01.2019)
}

\section{3}

Güvenlik Stratejileri

Cilt: 16

Say1: 35 
614

Güvenlik

Stratejileri

Cilt: 16

Say1: 35

Vietnam'daki asker sayısını peyderpey 533 bine çıkartan Johnson, ${ }^{40}$ hem halk hem de partisinin desteğini kaybetmiş ve Amerikan Tarihi'nin o döneme dek en yüksek oy oranı ile Başkan seçilmesine rağmen ikinci defa aday olmamıştır. ${ }^{41}$

\section{Johnson Doktrini'nin Türkiye'ye Etkileri}

27 Mayıs 1960 askerî müdahalesinden sonra Türkiye'deki demokratikleşme sorunu, ${ }^{42}$ “14'ler Olayı”nda görüldügüü üzere askerî cenahta solun güçlenerek çıkmasına, müdahaleyi yapan Amerikan yanlıs1 subayların tasfiyesine neden olmuştur. Müteakiben Talat Aydemir' in Sovyetler Birliği etkisindeymiş gibi görünen ${ }^{43}$ iki darbe girişiminin bastırılmasında yaşanan sıkıntılar, Başbakan İsmet İnönü’nün askerî ihtilalin örtülü baskısı nedeniyle etkisiz durumu, ${ }^{44}$ Türk-Amerikan ilişkilerini olumsuz yönde etkilemiştir.

Ekim 1962'deki Küba Füzeler Krizi sonrasında Doğu Akdeniz'de Polaris tipi nükleer denizaltıların seyrüsefere başlaması, Amerika'nın "Second Strike" açısından elini kuvvetlendirmiştir. ${ }^{46} \mathrm{Bu}$ keyfiyet

${ }^{40}$ Caro, a.g.e., p. Xvii.

41 "The President's Address to the Nation Announcing Steps To Limit the War in Vietnam and Reporting His Decision Not To Seek Reelection, 31 March 1968", http://www.lbjlibrary.net/collections/selected-speeches/1968-january-1969/03-31-1968.

html (Erişim Tarihi: 17.07.2019).

${ }^{42}$ Central Intelligence Agency, The Prospects For Turkey, 5 January 1962, p. 4.

43 Torumtay, Aydemir' in ikinci kalkışması esnasında Genelkurmay'ın karşısındaki kavşakta bütün gece boyunca Sovyetler Birliği Büyükelçiliği'ne ait araçların tur attıklarını ve Genelkurmay binasını gözlediklerini iddia etmiştir. Necip Torumtay, Orgeneral Torumtay'ın Anıları, Milliyet Yayınları, İstanbul, 1994, s. 45. Bunun dışında darbe girişimlerinin iki numarası Fethi Gürcan'ın, her ne kadar kendisi bu iddiayı reddetse de, ikinci kalkışma sonrasında Alman Büyükelçiliği'ne sığınması kayda değerdir. Kanımızca Gürcan'ın cezaevinden Barzani Aşireti'nin yardımıyla Irak'a kaçırılma olasılığı da Sovyet bağlantısını kuvvetlendirmektedir. Lütfen bkz. Fethi Gürcan, Ben Ihtilalciyim, (Yay-Haz) Öner Gürcan, Süvari Yayıncılık, Ankara, 2005, s. 291-2 ve Yeşim Demir; “Albay Talat Aydemir'in Darbe Girişimleri”, Çağdaş Türkiye Tarihi Araştırmaları Dergisi, Sayı:12, Bahar 2006, 155-171, s. 169.

${ }^{44}$ Ayrıntılı bilgi için bkz. CIA, a.g.r., p. 5.

45 İkinci Vuruş Yeteneği (Second Strike Capability): Nükleer saldırıya uğradıktan sonra, 
Soğuk Savaş: Amerikan Büyük Stratejisi, Johnson Doktrini ve Kıbrıs

Kütlevi Mukabele kavramında hasım kuvvete yakın bulunan ya da cephe hattındaki nizami ve konvansiyonel orduların eski önemini yitirmesine, başka bir deyişle Birleşik Devletler'in, Türkiye'ye olan ihtiyacının göreceli olarak azalmasına neden olmuştur. Bununla birlikte Sovyetlerin orta menzilli balistik füzelerini Türk sınırına konuşlandırması ile birlikte Türkiye'ye yönelik Sovyet tehdidi ters orantılı olarak artmıştır. ${ }^{47} 1958$ yılında Irak'taki askerî darbe ile Bağdat Paktı'nın oluşturduğu Sovyetlerin güneyinin çevrelenmesindeki "Northern Tier" (Kuzey Kuşak)'ın kopmas1 ise Irak'ın, Misır ve Suriye'nin ardından Sovyetler Birliği'nin nüfuz alanına girmesine neden olmuş, Orta Doğu'daki mevcut baskıyla Türkiye, 1963 itibarıyla kuzeyden gelen tehdit karşısında da kendisini daha yalnız ve tehlikede hissetmeye başlamıştır. ${ }^{48}$

Yine de 13 Şubat 1963 tarihli "The Prospects for Turkey" başlıklı raporda, bir y1l, hatta 1965 'teki seçimlere kadar iktidarda kalacağ 1 öngörülen İnönü yönetimindeki azınlık hükümetinin dış politikasında Sovyetler Birliği'nin başat düşman olarak addedildiği belirtilmiştir. Ayn1 raporda Sovyet Bloğu'na karşı mümkün olan yegâne koruma unsurunun hâlen Birleşik Devletler ve NATO olduğunun kabul edildiği

ilk vuruşu yapan ülkeye, ciddi bir karşı saldırı yapma yeteneğini korunaklı ortamlarda bulundurma imkânı "İkinci Vuruş Yeteneği" olarak tanımlanmaktadır. İkinci vuruş yeteneği "üçlü sayacağı" olarak (triad) olarak anılmaktadır ve üç temel sisteminden oluşmaktadır. Bunlar, denizaltılardan firlatılabilen uzun menzilli nükleer başlıklı füzeler (SLBM), yer altında korunaklı silolarda firlatılmaya hazır durumda tutulan nükleer başlıklı kıtalararası menzili sahip balistik füzeler (ICBM) ve en ileri alarm durumunda bulundurulan nükleer silah yüklü uzun menzilli ağır bombardıman uçaklarıdır. Ayrıntılı bilgi için bkz. Mustafa Kibaroğlu, "INF Krizinin Arka Planı ve Küresel Güvenliğe Etkileri”, Stratejist, Kasim 2018/16, 18-29, s. 23.

${ }^{46}$ Mustafa Kibaroğlu, "Turkey and Shared Responsibilities" in Shared Responsibilities for Nuclear Disarmament: A Global Debate, American Academy of Arts and Sciences, Cambridge, 2010, “24-27”, p. 25.

${ }^{47}$ CIA, The Prospects For Turkey, 17 January 1963, s. 21-22 ve https://www.cia.gov/library/ readingroom/docs/CIA-RDP79R01012A023700010022-6.pdf (Erişim Tarihi 30.04.2019).

${ }^{48}$ Behçet Kemal Yeşilbursa, Bağdat Paktı 1950-1959, Çev. Nur Nirven, Vakıfbank Kültür Yayınları, İstanbul, 2019, s. 24-27. 
616

Güvenlik Stratejileri

Cilt: 16

Say1: 35

değerlendirilmiştir: ${ }^{49}$

"Sovyet tehdidinin farkındalığı ve Türkiye ile Birleşik

Devletler arasındaki temel müsşerek menfaatler doğrultusunda, yakın ilişkilerin devam edeceğine inanıyoruz... Orta Doğu'da Türkiye muhtemelen ilk etapta Komünist ve Nasırcı nüfuzun yayılmasını engellemeyle ve Kıbrıs'taki Türk toplumunu korumakla ilgilenmeye devam edecektir."

Kasım 1963'te Johnson'ın Başkan olması ile birlikte iki taraf açısından yukarıdaki sorunların yanına Kıbrıs Meselesi de eklenmiştir. Kasım 1963'te Kıbrıs Cumhurbaşkanı Makarios tarafından Kıbrıs'ın iki toplumlu yapısını değiştirmek üzere yapılan anayasa tadili ile birlikte Kıbrıs Türkleri'ni yok etmek ve adayı Yunanistan'a bağlamak amacını güden Akritas Planı doğrultusunda sistematik imha hareketleri başlamıştır. Özellikle Aralık 1963'te literatüre "Kanlı Noel" olarak geçen Albay Grivas önderliğindeki EOKA-B tarafından başlatılan pogromlar, bine yakın Türk'ün ölümüne, 30 bin kadar Türk'ün ise Kuzey'e doğru sürülmesine neden olmuştur. ${ }^{50}$ NATO'nun güneydoğu kanadının iki komşu ve müttefik ülkesi olan Türkiye ve Yunanistan'1 konvansiyonel bir savaşın eşiğine getiren bu hadise, hâlihazırda Latin Amerika ve Asya Pasifik'te sıcak çatışmalara giren Birleşik Devletler'in meseleye doğrudan müdahil olmasına sebep vermiştir.

CIA tarafindan 28 Ocak 1964 tarihli "Cyprus: The Problem of Keeping the Peace" başl1klı Johnson'a sunulan raporda mevcut durum, tarafların tutumu ve en önemlisi Birleşik Devletler'in ne yapması gerektiği yedi maddede açıklanmıştır. İlk olarak Kıbrıs'taki Türk ve Rumların yaşanan son hadiseler 1şı̆̆ında karşıllklı güvensizlik nedeniyle ayrıştıkları ve adaya hâkim olan şiddeti yalnızca bir dış (askerî) müdahalenin durdurabileceğine yönelik duydukları endişe zikredilmiştir.

${ }^{49}$ CIA, The Prospects For Turkey, 13 February 1963, s. 2-3 ve https://www.cia.gov/library/ readingroom/docs/CIA-RDP79R01012A023700010010-9.pdf Erişim Tarihi (30.04.2019).

${ }^{50}$ Ayrıntılı bilgi için bkz. Ahmet Sanver, Akritas'a Karşı TMT, Yayınevi yok, Lefkoşe, 2012, s. 11-34; 40-98;102-112 ve 165-189. 
Soğuk Savaş: Amerikan Büyük Stratejisi, Johnson Doktrini ve Kıbrıs

Zira metne göre mevcut istikrarsız ateşkes kararının bozulması, Yunanistan'ın kendisini yanıt vermeye mecbur olduğunu hissedeceği, Türkiye tarafından aktif bir askerî müdahaleye yol açacaktır. ${ }^{51}$

Metindeki tahlile göre Garantör Devlet olma hasebiyle barışı korumanın esas yükünü taşıyan İngiltere ise, herhangi bir siyasi çözüm ihtimalinin olmadığı Kıbrıslı Türkler ve Rumlar arasındaki açmazda müphem bir rol oynamaktan kaçınmaktadır. Zira İngilizler barış1 sağlamak adına Londra ve Zürih Antlaşmaları'nın -ki bunların tekrar canlandırılması daha kapsamlı bir mutabakata ihtiyaç duyulması hasebiyle imkânsız görülmektedir- yetersiz olduğunu düşünmektedirler. Bununla birlikte hem İngiltere'deki hem de Kıbrıs'taki siyasi şartlar nedeniyle adada barışı tek başlarına muhafaza edemeyeceklerini kabul etmektedirler. Analize göre de bu yargı doğrudur. Zira çözümsüzlüğün uzaması, adadaki düzeni sağlamak veya eski haline döndürmek için Garantör Devletler'in dışında bir dış müdahaleye ihtiyacı ortaya çıkmıştır. ${ }^{52}$

Dördüncü maddede ise diğer iki Garantör Devlet'e değinilmiş, her iki tarafın uzlaşmaz ve kavgacı tutumlarına karşılık, tarafların adaya yayılan ve gün geçtikçe artan şiddet eylemlerinden tıpkı adadaki soydaşları gibi rahatsız oldukları dile getirilmiştir. Bu hususta bazı Kıbrıslı Rum liderlerin çözüm için Birleşmiş Milletler, İngiltere ya da Yunanistan yerine NATO üyelerinden müteşekkil bir Barış Gücü'nü tercih edeceklerinin zikredilmesi kayda değerdir. Zira Türkiye sadece adadaki birliğinin varlığını devam ettirmek ya da birlik sayısını arttırmayı önemsemekle birlikte, Birleşmiş Milletler'in hassas bir bölge olan Kıbris Adası'nda Sovyet etkisinin yayılmasını engelleyemeyeceğinden kuşkulanmaktadır. Yine de her iki tarafta da ne tür bir "Barış Gücü"nün adada konuşlandırılması ile alakalı belirgin bir tutum görülmemekle birlikte neredeyse ilgililerin hepsi ABD'nin başat unsur olarak dahli olmadığı hiçbir barışı koruma girişimine

\footnotetext{
${ }^{51}$ CIA, Cyprus: The Problem of Keeping the Peace, 28 January 1964, p. 1.

52 Ayrıntılı bilgi için bkz. https://www.cia.gov/library/readingroom/document/cia-rdp 79r00967a000900010013-8 (Erişim Tarihi 28.04.2019).
}

\section{7}

Güvenlik Stratejileri

Cilt: 16

Say1: 35 
618

Güvenlik Stratejileri

Cilt: 16

Say1: 35

güven duymamaktadır. ${ }^{53}$

Altıncı maddede Türkiye'nin adaya askerî müdahalesi ikinci kez Aralık 1963 'teki olaylar üzerinden ima edilmiştir. Kıbrıslı Türklerin, uğradığı can ve mal kayıpları sonrası Ankara'nın adadaki soydaşlarının güvenliğini sağlama hususunda "en güvenilir müttefiki"ne dahi sorumluluk vermeyeceği zikredilmiş, başka bir deyişle Türklerin son hadiseler 1şığında "gözünü kararttığı" ifade edilmiştir. Metnin devamında olası bir barışı koruma gücü için Kıbrıs Cumhurbaşkanı Makarios'un tutumu ele alınmış, Birleşik Devletler'in desteğinde Garantör Devletler'in oy birliği ile Barış Gücü'nü kabul edeceği tespit edilmiştir. Bununla birlikte Makarios'un onayının BM'de Sovyet Bloğu'ndan gelecek baskıların "önüne geçeceğine" ve birçok Asya ve Afrika ülkesinin asker göndermesi için hukukî bir gerekçe olacağına değinilmiştir. ${ }^{54}$

Birleşik Devletler'in olaya neden müdahil olması gerektiğini açıklayan son madde, Soğuk Savaş'ın "Büyük Strateji”si ve yukarıda belirtilen argümanlar çerçevesinde değerlendirilebilir. Buna göre:

"ABD barışı koruma girişiminde açıkça ve tam olarak yer almadığı sürece, Kıbrıslı topluluklar ve bir dereceye kadar Yunanlılar ve Türkler, makul uzlaşı arayışlarında samimi davranmayacaklardır. Zira tarafların her biri, ABD'ye şahsi itirazlarda bulunarak kendi çıkarlarını ilerletme eğiliminde olacaklardır. Bununla birlikte, bir antlaşma söz konusu olduğunda, ABD'nin mutabakata varılıncaya kadar kesinlikle bu mesele ile meşgul kalacağı, ki bir anlaşmanın bulunmasının zor olacağı da kabul edilmelidir, kaçınılmazdır."

Ocak-Haziran 1964 arasında Türkiye ve ABD arasında Kıbrıs gerginliğinin aşamalı şekilde arttı̆̆ görülmektedir. Bu durum Başkan'ın Dışişleri Bakanı Rusk ve Savunma Bakanı McNamara ile dış politikaya dair telefon konuşmalarına da yansımıştır. Johnson'ın 29 Ocak 1964'te

${ }^{53}$ CIA, Cyprus: The Problem of Keeping the Peace, p. 2-3.

${ }^{54}$ A.g.r., p. 3-4.

${ }^{55}$ CIA, Cyprus: The Problem of Keeping the Peace, p. 4. 
Soğuk Savaş: Amerikan Büyük Stratejisi, Johnson Doktrini ve Kıbrıs

McNamara ile yaptığı görüşmede, McNamara, "Türklerle iletişim eksikliğinden" hayıflanarak, Türklerin tüm teklifleri geri çevirdiğinden bahsetmiştir. ${ }^{56}$ Yine Johnson'ın 2 Mart 1964'te Rusk ile yaptı̆̆ 1 telefon görüşmesinde, Başkan 1srarla "Panama İşi”"nin üzerinde durmuş ve Rusk'ın Kıbrıs ile alakalı "Türklerden haber bekliyoruz" demesi karşısında sessiz kalmış ve konuyu değiştirmiştir. ${ }^{57}$ Çünkü Johnson'ın zihni Ocak ayında Panama'da baş gösteren sorunla meşguldür ve bu meşguliyet diğer uluslararası sorunların önüne geçmiştir. Amerikan Başkanı için arka bahçesinde uluslararası komünizmin etkisini genişletecek bir devrim süreci her şeyin önündedir ve bu coğrafyadaki olumsuz gelişmeleri Amerikan kamuoyuna ve Kongre'ye izahta ciddi sikıntı yaşayacaktır.

7-10 Mart tarihlerini kapsayan CIA tarafindan düzenli olarak Başkan'a takdim edilen “Intelligence Review"un ilk sırasında yer alan Kıbrıs başlığındaki analiz-yorumda durumun vahim bir hal aldığı zikredilmiş, çatışmaların tüm adaya yayıldığ 1 ve Rum "güvenlik güçlerinin" Kıbrıslı Türklere karşı savaş açtığı ifade edilmiştir. BM temsilcisi ve İngiltere'nin Rumları caydırmak hususunda hiçbir şey yapmadığı ve bu durumun olası Türk askerî müdahalesini arttırdığı kaydedilmiştir. Keza Türk Dış İşleri Bakanı Erkin, İngiltere'ye Türklere yönelik şiddetin durdurulması için ivedi tedbirler alınması için başvurmuş ve Amerikan'ın Ankara Büyükelçisi Hare'a bir kez daha olası Türk müdahalesinde Amerikan'ın nasıl bir tavır takınacağını sormuştur. $^{58}$

\footnotetext{
56، Telephone conversation \# 1644, sound recording, Lyndon B. Johnson and Robert Mcnamara, 29 January 1964, 6:32 PM", https://www.discoverlbj.org/item/tel-01644 (Erişim Tarihi: 19.01.2019).

57،"Telephone conversation \# 2305, sound recording, Lyndon B. Johnson and Dean Rusk, 2 March 1964, 11:35 AM", https://www.discoverlbj.org/item/tel-02305 (Erişim Tarihi: 19.01.2019).

58 CIA, The President's Intelligence Review, 7-10 March 1964, p. 2-3 ve https://www.cia.gov/library/readingroom/docs/DOC_0005996883.pdf (Erişim Tarihi: 19.01.2019)
}

\section{9}

Güvenlik Stratejileri

Cilt: 16

Say1: 35 
620

Güvenlik Stratejileri

Cilt: 16

Sayı: 35

Raporda da ifade edilen meclis kararı, 16 Mart 1964'te "Kıbrıs'a Türk Silahlı Kuvvetleri'nin gönderilmesine izin verilmesini" içeren tezkeredir. Meclis'te oylamaya katılan 491 milletvekilinin 487'si tezkereyi onaylamış ve Türkiye, ABD ve Garantör Devletler'e karşı hukukî icazetini alarak askerî müdahale konusundaki ciddiyetini taraflara göstermiştir. 16 Mart günü 1930 tarihli Türk-Yunan Antlaşması'nın feshedilmesi açısından da önem arz etmektedir. Zira bu antlaşmanın tanıdığ vatandaşı Rum'un altı ay içerisinde sınır dışı edilmesi kararı alınmış, bu karar yasa dışı eylemlere karışan birkaç Rum'a da hemen uygulanmıştır. ${ }^{59} \mathrm{Bu}$ karar ile İnönü hem iç politikada Kıbrıs Meselesi doğrultusunda sert bir tavır takınacağı izlenimi yaratmış, hem de dış politikada Makarios'a güçlü destek veren Yunanistan'a gözdağı vererek, gelecekteki müzakerelerde Atina'ya diplomatik arenada bask1 yapma firsatı kazanmıştır. ${ }^{60}$

Meclis kararlarından sonra yayımlanan bir raporda "Türkler, askerî müdahale tehdidinin adadaki göreceli sükûneti sağladığına ve Kıbrıslı Rumların gözünü korkuttuğuna inanmalarına" rağmen aslında Türklerin bu tehditlerinin etkisinin kısa süreli olduğunun farkında oldukları zikredilmiştir. Zira "Türkler, muhtemelen BM Gücü’nün barışı sağlayamadığı noktada harekete geçecek gücün alternatifsiz bir şekilde kendileri olduklarını hissediyorlar ve kanımızca müdahaleye hazır olmaya devam edeceklerdir."

Mart ayının sonlarına doğru devlet güdümlü Rum tedhişçilerin Türklere karşı sistematik imha eylemlerinin devam etmesi, Türkler

59 CIA, Weekly Summary, 27 March 1964, p. 11 ve https://www.cia.gov/library/ readingroom/docs/CIA-RDP79-00927A004400050001-0.pdf(Erişim Tarihi: 19.01.2019)

60 CIA, The President's Intelligence Checklists, 18 March 1964, p.2 ve https://www.cia.gov/library/readingroom/docs/DOC_0005996898.pdf (Erişim Tarihi: 19.01.2019)

${ }^{61}$ CIA, The President's Intelligence Checklists, 16 March 1964, p. 2; https://www.cia.gov/ library/readingroom/docs/DOC_0005996893.pdf ve CIA, The President's Intelligence Checklists, 17 March 1964, p. 2-3 ve https://www.cia.gov/library/readingroom/ docs/DOC_0005996895.pdf (Erişim Tarihi: 19.01.2019) 
Soğuk Savaş: Amerikan Büyük Stratejisi, Johnson Doktrini ve Kıbrıs

açısından tekrar bir müdahale uyarısının yapılmasını gerekli kılmıştır. Lakin bu sefer Türkiye, inandırıcılığ 1 ve caydırıcılığını kaybetmemek adına Amerika Birleşik Devletleri'ne başvurarak Rumlara müdahalenin siyasi bir manevra olmadığını anlatmalarını istemiştir. 20 Mart'ta Başkan'a takdim edilen vesikada, Kıbrıslı Rumların "bu tür eylemleri" tehlike noktasına kadar getirip, Türkiye harekete geçmeden geri çekildikleri ifade edilmiştir. ${ }^{62}$ Başka bir deyişle karar verme mekanizmasını yönlendirmek doğrultusunda kaleme alınan vesikada Aralık 1963 'ten itibaren artan tedhiş ve terör faaliyetlerinin BM Barış Gücü'nün adaya konuşlanmasına rağmen benzer bir seyir izlediği ve diplomatik kanalların çaresiz kaldığı ima edilmiştir.

İstihbarat belgelerinden de görüleceği üzere adadaki gerilim ve buna bağlı Türk müdahale ihtimali ilerleyen aylarda tedricen yükselmiştir. Nisan ayının ortalarına doğru Rumların Türklerin kontrolündeki LefkoşeGirne yolu üzerinde terör faaliyetlerini hızlandırması sonrasında bölgedeki Türk Birliği’nin (KTKA) asayişi sağlamak üzere karayolunu kontrol altına alması ancak BM Genel Sekreteri U Thant'ın girişimi ile Barış Gücü'ne birkaç gün sonra teslim edilerek sonlandırılmıştır. ${ }^{63} \mathrm{Bu}$ olayın öncesinde Türkiye'nin adadaki Rum tedhiş faaliyetlerine rağmen her geçen gün Kıbrıs siyasetinde yalnızlaşması nedeniyle ABD'yi suçladığı görülmektedir. ${ }^{64}$ ABD'nin ikircikli politikası ve iki müttefiki arasında adilane olmayan yaklaşımı karşısında şu çarpıcı tespit yapılmıştır:

“Türkler, ABD'nin Makarios'a ve Yunanistan'a bask1 yapma konusundaki isteksizlik ve yetersizliği karşısında adeta acı çekiyorlar."

28 Nisan'daki raporda ise, Kıbrıslı Rumların, tıpk1 “antik Yunan trajedilerinde olduğu gibi” amansız bir şekilde felakete doğru

\footnotetext{
${ }^{62}$ CIA, The President's Intelligence Review, 18-20 March 1964, p. 2 https://www.cia.gov/ library/readingroom/docs/DOC_0005996904.pdf (Erişim Tarihi: 19.01.2019)

${ }^{63}$ CIA, The President's Intelligence Review, 15-17 April 1964, p. 3.

${ }^{64}$ CIA, The President's Intelligence Review, 11-14 April 1964, p. 2.

${ }^{65}$ CIA, The President's Intelligence Review, 15-17 April 1964, p. 4.
}

\section{1}

Güvenlik Stratejileri

Cilt: 16

Say1: 35 
622

Güvenlik Stratejileri

Cilt: 16

Sayı: 35 sürüklendiği söylenmiş ve Kıbrıslı Türklerin lideri Dr. Küçük'ün adada yaşayan Türklere gönderdiği mesaja yer verilmiştir. Dr. Küçük; Rumların katliamlardan vazgeçmediği ve buna karşın BM'nin çaresiz kaldığı, durumun "ölüm-kalım" meselesine doğru evrilmesi nedeniyle Türk yerleşimlerine giden yolların barikatlarla kapatılması ve baskınlara karşı hazırlıklı olunması talimatını verdiği bildirilmiştir. Aynı raporda Türk Silahlı Kuvvetleri'nin İskenderun ve çevresinde harekete geçtiği ve son günlerde bazı Kıbrıslı Türklerin Ankara'nın adım atmasını beklediklerine yönelik bir intiba vermelerine rağmen Dr. Küçük'ün Türkiye'nin müdahalesini sağlamak üzere son bir tasavvurunun olup olmadığının bilinmediği kaydedilmiştir. ${ }^{66}$

Öte yandan Rumlar için gidişatın memnun edici olduğu söylenmekle birlikte İçişleri Bakanı Georkatzis'in denetimindeki silahlı birliklerin Girne Geçidi'ni koruyan Türklerin ana sığınağı St. Hilarion Kalesi'ne dayandıkları ve BM Gücü'nün onları durdurmak için hiçbir girişimde bulunmadığ belirtilmiştir. $^{67} 19$ Mayıs'taki raporda ise Rum liderlerin özellikle Sovyet Bloğu'ndan silah ve askerî yardım almaya devam ettikleri ve yakın zamanda polis ve jandarmayı birleştirerek zorunlu askerlik yasası çıkaracaklarını söyledikleri yer almıştır. Bununla birlikte BM'nin yaptığı açıklamaya göre Mart ayından itibaren rehin durumundaki 91 Kıbrıs Türkü'nün 74'ü öldürülmüsstür. ${ }^{68}$

Mayısın sonlarına doğru adada devlet kontrolünün tamamen ortadan kalktığı görülmektedir. Zira 22 Mayıs tarihli rapora göre Makarios, Kıbrıslı Rum fanatikleri artık kontrol edemediğini itiraf etmiş, raporu kaleme alanın tespitine göre her kesimden gelen uyarılara rağmen kendi geleceğini tehlikeye atarak Kıbrıs'ta anarşinin yükselmesine izin vermiştir. Amerikan'ın Kıbrıs Büyükelçisi Belcher ise Türk gayrinizami kuvvetlerinin şayet Türk rehinelerin öldürüldüğü

${ }^{66}$ CIA, The President's Intelligence Checklists, 28 April 1964, p. 2.

${ }^{67}$ A.g.r., p. 3.

${ }^{68}$ CIA, The President's Intelligence Review, 16-19 May 1964, p. 4-5. 
kesinleşirse karşı saldırı başlatacaklarını bildirmiştir. ${ }^{69}$

Johnson Doktrini'nde "Batı Yarımküre" öncelikli bir paradigma benimsenmesine rağmen iki NATO müttefiki olan Türkiye ve Yunanistan'ın adadaki siyasi çözümsüzlük sonucunda çatışmanın eşiğine gelmesi ve adaya yönelik her an gerçekleşebilecek Türk askerî müdahalesi Birleşik Devletler açısından iki müttefik arasındaki dengenin kaybolması endişesiyle Johnson Mektubu'na giden süreci tetiklemiştir. Olası bir Türk-Yunan çatışması ve Doğu Akdeniz'de statükoyu bozacak ve Sovyet etki alanını genişletecek müphem her durum, Soğuk Savaş’taki Amerikan Büyük Stratejisi'nin maddi unsuru olan "Sovyetlerin Çevrelenmesi" kuramına tezat teşkil edecektir. Bu sebeple büyük stratejinin nihai gayesine doğrudan zarar verecek bir hamle olarak değerlendirilen müdahale ihtimali hegemon güç tarafindan sert bir müdahale ile engellenmiştir.

\subsection{Johnson Mektubu'nun Türkiye'nin Kıbrıs Politikasına Etkisi}

5 Haziran 1964'te Başkan Johnson'1n, Türkiye Cumhuriyeti Başbakanı İsmet İnönü'ye gönderdiği mektup, Türk-Amerikan ilişkilerinde ilk ciddi kriz olarak addedilmektedir. Zira mektup sonrası Türk-Amerikan ilişkileri Türk kamuoyunda sorgulanmaya başlamış, Türkiye'de sol akımların hatta silahlı kuvvetlerin bir kısmının "AntiAmerikancı" söylemlerini şiddetlendirmesine yol açmıştır. Bununla birlikte Türkiye'nin Kıbrıs Meselesinde geri adım atması, 1965 yılındaki seçimlerde iktidar değişimine sebep olmuş ve 12 Mart Muhtırası'na kadar Süleyman Demirel önderliğindeki Adalet Partisi Türkiye'yi tek başına yönetmiştir.

Mektupta net bir şekilde görüldüğü üzere Birleşik Devletler, Türkiye'nin tek başına Kıbrıs'a müdahalesine karşıdır. Johnson, ilk etapta bunun ikili taahhütlere uymadığını zikretmiş ve ardından Türkiye tarafindan tek taraflı bir müdahale olduğu takdirde nelerin olacağını sert bir retorikle muhatabına anlatmıştır. İlk etapta Türk-

\footnotetext{
${ }^{69}$ CIA, The President's Intelligence Review, 20-22 May 1964, p. 4.
} 
624

Güvenlik Stratejileri

Cilt: 16

Say1: 35

Yunan çatışmasının NATO konseptine aykırı olmakla birlikte bu çatışmanın ardından olası bir Sovyet müdahalesinde Türkiye'nin NATO'nun 5. Maddesi mucibince müttefikleri tarafindan korunmayacağı ifade edilmiştir. Ayrıca Türkiye'nin olası bir harekâtında Birleşik Devletler'den aldığı askerî teçhizatın kullanılmasına izin verilmeyeceği ve bu gerekçeler yüzünden başarısız olacak olan harekât esnasında adadaki Türklerin katledileceği zikredilmiştir. Son olarak mektupta alınan tüm müspet veya menfi kararların Birleşik Devletler'in onayı olmadığı için Türkiye tarafından iptal edilmesi gerektiği açık bir şekilde deklare edilmiştir. ${ }^{70}$

5 Haziran tarihli "Intelligence Review"un ilk sirasinda yer alan "Kıbrıs" başlığında, "Türklerin müdahale tehdidinin görünüşe göre şimdilik geçtiği lakin uzun vadeli tehlikenin hâlen devam ettiği" zikredilmiştir. Zira belgede Türk Silahlı Kuvvetleri'nin hâlen tam teyakkuz halinde olduğu ve Kıbrıslı Türklerin, Türk Ordusu'nun yardımlarına gelmelerini sağlamak üzere tasarlanmış bir saldın başlatabilecekleri ifade edilmiştir. ${ }^{71}$

Mektuptan bir gün sonra 6 Haziran tarihli "Başkan Johnson'1n, Başbakan İnönü'ye gönderdiği Mektuba Yönelik Türk Tepkileri" başlıklı CIA telgrafındaki analiz dikkat çekmektedir. Mektubun, Birleşik Devletler'in “Türk niyetleri ve Türkiye'nin Kıbrıs'taki pozisyonunu ne geçmişte ne de hâlihazırda anlamadığına dair (iyi) bir örnek olduğu" söylenmiş ve "Türk-Amerikan ilişkilerinde başka herhangi bir gelişmeden daha ciddi bir gerilemeye yol açacağına" işaret edilmiştir. Zira Türk tarafi açısından "Birleşik Devletler Başkanı'nın, böylesi bir mektup gönderebilmesinin ciddi bir sarsıntı ve güvensizlikten ziyade tam bir hayal kırıklığı yarattığı" ve "hatta bazılarının daha da ileriye giderek bu mektup nedeniyle (Türkiye'nin Kıbrıs’a) müdahaleyi ertelememesi gerektiği”nin düşünüldüğü dile

70 Mektubun tamamı için bkz. "Johnson Letter", https://tr.scribd.com/document/ 38718043/Johnson-Letter (Erişim Tarihi: 19.01.2019)

${ }^{71}$ CIA, The President's Intelligence Review, 3-5 June 1964, p. 2 ve https://www.cia.gov/ library/readingroom/docs/DOC_0005959220.pdf (Erişim Tarihi: 19.04.2019) 
Soğuk Savaş: Amerikan Büyük Stratejisi, Johnson Doktrini ve Kıbrıs

getirilmiştir. Telgrafta son olarak Türklerin genel kanısının "bu mektubun, Türkiye'nin uluslararası arenada Birleşik Devletler'den daha bağımsız hale gelmesini neredeyse zorunlu hale getirdiği" yönünde olduğu zikredilmiştir. ${ }^{72}$

6-9 Haziran 1964 tarihlerini kapsayan "Intelligence Review"un ikinci sırasında yer alan "Kıbrıs-Türkiye" başlığında ise "Türkiye'de İnönü'nün ABD baskısı nedeniyle son dakika müdahaleyi iptal etmesi kaynaklı politik bir firtınanın koptuğu" zikredilmiş, yerel basının mektubun tüm ayrıntılarına ulaşması hasebiyle İnönü'nün başının dertte olduğu"73 kaydedilmiş ve şöyle devam edilmiştir:

"Türkler, olayların seyrinin bu yönde devam etmesine izin verilirse, Kıbris'1 kaybedecekleri konusunda giderek endişelenmeye başladı. Bildiğimiz üzere onların korkularını arttıran BM arabulucusu Tuomioja'nın durumun umutsuz olduğuna yönelik izlenimleri ve eninde sonunda adanın Yunanistan ile birlik kurabilme ihtimalidir." ${ }^{, 74}$

Aynı tarihli başka bir belgeden Türkiye'nin yukarıdaki kaygılarının pek yersiz olmadığı anlaşılmaktadır. Zira İngiltere Dış İşleri Bakanı Butler, George Ball ile görüşmesinde, Doğu Akdeniz'de ikinci bir Küba tehdidini engellemek ve "durumu yönetebilecek güvenilir ellere" ihtiyaç nedeniyle adanın bir şekilde Yunanistan ile birleşmesinin en iyi seçenek olacağı dile getirmiştir. ${ }^{75}$

Mektubun hem iç politikada yarattığ politikada Kıbrıs'1 kaybetme tehlikesi Türk tarafı açısından üslubun sertleştirmesine yol açmıştır. Zira aynı belgeye göre İnönü, ABD seyahati öncesinde Büyükelçi Hare'a, mektubun etkisiyle Birleşik Devletler'in kendisi ile anlaşmanın kolay olacağı fikrine kapılmaması

\footnotetext{
72 Telgrafin orijinali için ltfn bkz. https://www.cia.gov/library/readingroom/ docs/DOC_0000615268.pdf (Erişim Tarihi: 19.04.2019).

${ }^{73}$ CIA, The President's Intelligence Review, 6-9 June 1964, p. 3 ve https://www.cia.gov/ library/readingroom/docs/DOC_0005959227.pdf(Erişim Tarihi: 19.04.2019).

${ }^{74}$ a.e.

${ }^{75}$ CIA, The President's Intelligence Checklists, 9 June 1964, p. 3
}

\section{5}

Güvenlik Stratejileri

Cilt: 16

Say1: 35 
626

Güvenlik Stratejileri

Cilt: 16

Sayı: 35

gerektiğini söylemiştir. ${ }^{76}$ Yine bu doğrultuda İnönü'nün Amerika ziyareti öncesinde meclisten güvenoyu almasına yönelik manevras1, özellikle iç politikadaki muhalif tenkitleri susturarak Amerika'ya güçlü bir destekle ile gitmek ve Kıbrıs Meselesi'nin bir hükümet politikasından ziyade "millî bir dava" olduğu izlenimi yaratmaktır.

17 Haziran tarihli raporda ise "Cuma günü yapılacak oylamada Ana Muhalefet Partisi olan Adalet Partisi'nin oylamada ret oyu vereceği" tahmin edilmiş ${ }^{77}$, şayet İnönü mecliste güçlü bir destek alamadığ 1 takdirde -bu durumun Washington'a yapacağ 1 ziyarete gölge düşüreceği hasebiyle- çıkan sonuca göre Washington ziyaretini iptal bile edebileceği ima edilmiştir. Lakin son tahlilde kıl payı oylamayı kazanacak olan İnönü'nün 'Kıbrıs'ta olası bir anlaşma için verebileceği tavizleri onaylaması için Meclis'i ikna edemeyeceği" düşünülmektedir. ${ }^{78}$

İnönü, 19 Haziran tarihli güvenoyunu öngörüldüğü üzere sadece altı oy farkla kazanabilmiştir. Bu keyfiyette muhalefet partilerinden elli milletvekilin oylamaya katılmaması da etkili olmuştur. ${ }^{79} 20$ Haziran'daki analizde ise muhalefetin kritik bir kavşakta iktidarı almak istemediği, sadece İnönü'nün Washington'daki pazarlıkta elini zayıflatarak ona "hiçbir şey vermemesi gerektiğini" hatırlattığı tespiti yapılmıştır. ${ }^{80}$

İnönü, oylamadan sonra istifa kararından vazgeçmiş ve programı doğrultusunda 21/22 Haziran'da Amerika Birleşik Devletleri ziyaretini gerçekleştirmiştir. ${ }^{81}$ Amerika' dan eli boş döneceği ihtimali karşısında

${ }^{76}$ A.g.r., p. 4.

${ }^{77}$ CIA, The President's Intelligence Checklists, 17 June 1964, p. 3 ve CIA ,Bulletin, Current Intelligence Relating to National Security, 18 June, 1964, p. 4.

${ }^{78}$ CIA, The President's Intelligence Checklists, 18 June 1964, p. 2.

${ }^{79}$ CIA, The President's Intelligence Checklists, 18 June 1964, p. 2 ve CIA, Bulletin, Current Intelligence Relating to National Security, 20 June 1964, p. 4.

${ }^{80}$ CIA, The President's Intelligence Checklists, 20 June 1964, p. 2.

${ }^{81}$ Amerikalılar bunu 19 Haziran tarihinde biliyorlardı. Bkz. CIA, The President's Intelligence Checklists, 19 June 1964, p. 2. 
hem ABD'ye hem de iç muhalefete gözdağı vermek üzere seyahati sırasında Kıbrıs Meselesi'ne dair istişarelerde bulunmak üzere Avrupa'ya gitmeyi kararlaştırmıştır. 28 Haziran'da Londra'ya uğrayan İnönü, 30 Haziran'da ise Fransa'da de Gaulle ile görüşmüştür. ${ }^{82}$ Lakin 30 Haziran tarihli bir analiz-yorumda dış temasların iç muhalefette herhangi bir yumuşama sağlamadığı, Türkiye'deki darbe söylentilerinin Kıbrıs'ta tansiyonu arttırdığı ve düşük yoğunluklu çatışmaların adanın kuzeybatısında tekrar başladığı belirtilmiştir. ${ }^{83}$

25 Ağustos 1964 tarihli "Intelligence Checklist"te ise, Başbakan'ın Kıbrıs politikası nedeniyle muhaliflerinin güç kazandığı; muhalefet ve ordunun hava saldırılarını durdurduğu için hükümeti eleştirdiği ve "kendi partisinin önde gelen üyeleri dahi" hükümetin politikalarının yetersiz olduğunu düşündükleri ifade edilmiştir. Bununla birlikte Kara Kuvvetleri'ndeki yeni atamalarla birlikte ordu içindeki İnönü yanlılarının zayıfladığı, kamuoyunda ise İnönü'ye yönelik eleştirilerin, anti-Amerikan söylemle birleştiği, bazı Türklerin onu "Amerikan baskı taktiklerini tolere etmesi" nedeniyle suçladığı kaydedilmiştir. Raporda dikkat çeken en önemli ayrıntı ise askerlerin NATO'ya dair tasavvurlarıdır. Genel izlenim, karar verme mekanizmasında bulunan askerî erkânın "tam anlamıyla NATO'ya dair hayallerinin yıkıldı̆̆gı" yönündedir. ${ }^{84}$

Johnson Mektubu ile Birleşik Devletler'in NATO müttefiki Türkiye'ye karşı sert tutumu, Makarios ve Kıbrıslı Rum liderleri daha da radikalleştirmiştir. Zira mektuptan sonra Kıbrıslı Türklere yönelik iktisadi tecrit ve ambargo uygulanmaya başlanmakla birlikte ${ }^{85}$ Makarios ve sair liderler tarafindan Yunanistan ile birleşme (ENOSIS) çabaları hızlandırılmış, adadaki İngiliz üslerinin kapatılması gündeme getirilmiş $^{86}$ ve Sovyetler Birliği'nden iktisadi ve askerî yardım alma

\footnotetext{
${ }^{82}$ CIA, The President's Intelligence Checklists, 22 June 1964, p. 2.

${ }^{83}$ CIA, The President's Intelligence Checklists, 30 June 1964, p. 2.

${ }^{84}$ CIA, The President's Intelligence Checklists, 25 August 1964, p. 3.

${ }^{85}$ CIA, The President's Intelligence Checklists, 18 July 1964, p. 2.

${ }^{86}$ CIA, The President's Intelligence Review, 29 August-1 September 1964, p. 4.
}

\section{7}

Güvenlik Stratejileri

Cilt: 16

Say1: 35 
628

Güvenlik Stratejileri

Cilt: 16

Say1: 35

girişimlerinde muvaffak olunmuştur. ${ }^{87}$

Birleşik Devletler, mektuptan sonra Başpiskopos Makarios'un adada asayişi sağlamak üzere otoritesini tekrar kurmaya çalışacağını ve kısa vadede Mısır ve Sovyetler Birliği'ne daha da yakınlaşacağını tahmin etmesine rağmen bu süreci engelleyememiştir. ${ }^{88}$ Neticede olas1 bir Türk müdahalesi ertelenmiş, adadaki asayişsizlik ve sürüncemeli durum gün geçtikçe katlanarak artmıştır.

\section{Sonuç}

Soğuk Savaş’ta Amerikan Büyük Stratejisi, hasım kuvvetin savaşma kabiliyeti, kudretini istinat ettiği manevi kuvvetleri, bağlı oldukları ideolojik yapı ve soyut gerekçeler etkisiz hale gelene kadar sürdürülebilirliğini korumuştur. Büyük Strateji'nin manevi unsuru olan "Amerikan Yaşam Tarzı" ve maddi unsuru olan Sovyetleri "Çevreleme" kuramı, 1991 yılında Sovyetler Birliği’nin dağılmasına kadar değişmeden benimsenmiştir. Piramidin ikinci kısmında yer alan ve Ulusal Güvenlik Belgelerine denk gelen "İstikrar Stratejisi" ise çok az değişikliğe uğramıştır. NSC 68 ve onun ilk evrimleştiği NSC 162/2'ye, Eisenhower, Kennedy ve Johnson dönemlerinde sadık kalınmıştır. Eisenhower'ın Kütlevi Mukabele kavramının, Kennedy ve Johnson dönemlerinde "Esnek Karşılık"a evrilmesi ise hasım kuvvet yani "uluslararası komünizm" in hamlelerine karşı taktik seviyedeki bir değişiklik olarak karşımıza çıkmaktadır. Zira başarısız Domuzlar Körfezi Olayı ve Küba Füze Krizi, nükleer doktrin ve örtülü operasyonların son bulmasına neden olmuştur. Birleşik Devletler'in "İkinci Vuruş”ta elini kuvvetlendirmesi, Sovyetlerin Amerikan Kalesi'ne yaklaşarak nükleer doktrini uygulanmaz kılmasının da

${ }^{87}$ CIA, Bulletin, Current Intelligence Relating to National Security, 1 October 1964, p. 8.

${ }^{88}$ CIA, The President's Intelligence Checklists, 25 July 1964, p. 4. Makarios-Nasir iş birliği için bkz. CIA, The President's Intelligence Checklists, 31 August 1964, p. 3. Ağustos ayında Rusların her ne kadar propaganda amaçlı olsa da Kıbrıs Krizi'nde kendilerine hızlı bir şekilde dâhil olup alan açacakları tahmin edilmiştir. CIA, The President's Intelligence Review, 12-14 August 1964, p. 4. 
etkisiyle yeni konsepte konvansiyonel ve doğrudan (açık) müdahale ön plana çıkmıştır.

Johnson döneminde Sovyetlerin Latin-Orta Amerika açılımı, uluslararası komünizmin Batı Yarımküre'de güç devşirmesine sebep olmuştur. Bu dönemde Johnson'ın iki kıtadaki “özgür Amerikanlar" retoriği, hasıma karşı yerel unsurların kullanılmasını gerekli kılmıştır. Dominik Cumhuriyeti'ndeki müdahaleden sonra bölgede askerî güç olarak 2 yıl daha kalan Inter-Amerikan Barış Gücü, bu dönemdeki "ortak ilkeler ve ortak hedefler" düsturunun en somut örneği olarak karşımıza çıkmaktadır. Bu dönemde Asya Pasifik'te ise Çin Halk Cumhuriyeti ile başlayan komünist "Domino Etkisi”nin kırılması için Sovyetlerin İç Hilal olarak adlandırılan bölgede sınırlandırılması ehemmiyet kazanmış ve Birleşik Devletler Vietnam Savaşı'na doğrudan müdahil olmuştur. Lakin bölgede yarım milyonu aşan Amerikan askerî varlığı ve sayıları 30 bini aşan kayıpların verilmesi, iç politikada sosyal devlet ve eşit haklar paradigmasıyla kamuoyunu arkasına alan Johnson Yönetimi'nin giderek halk desteğini kaybetmesine yol açmıştır.

Türkiye'de 27 Mayıs ihtilalinden sonra ortaya çıkan demokratikleşme sorunu, hasım kuvvetin güdümünde gerçekleştiği intibanı veren askerî darbe girişimleri ve özellikle 60'l1 yılların ikinci yarısında Türk kamuoyu ve siyasal hayatında farklı fraksiyonlardaki sol akımların güçlenmeye başlaması geçen on yıla nazaran TürkAmerikan ilişkilerinin gerilmesine yol açmıştır. Bunun dışında Kennedy dönemi ile birlikte Kütlevi Mukabele kavramının terk edilmesi, Türkiye'nin bu nükleer doktrin doğrultusunda cephe hattındaki önemini azaltmıştır. Yine iki NATO müttefiki arasında yaşanan Kıbrıs Meselesi ve Türkiye'nin adaya tek taraflı müdahalede bulunmak istemesi Türk-Amerikan ilişkilerinin ilk ciddi açmazı olmuştur. Rumların ENOSIS doğrultusunda adadaki Türklere yönelik sistematik katliamları ve Garantör Devlet İngiltere'nin ve BM'nin bu konuya karşı duyarsızlığ 1 ve çaresizliği Amerikan istihbarat belgelerine de yansımıştır. Mamafih, dönem itibarıyla, Türkiye'nin Kıbrıs'a yönelik siyaseti Amerikan Büyük Stratejisi gerçekliğine çarpmıştır. Johnson Mektubu Türk siyasi karar alıcılarının Atlantik Paktı ile 
630

Güvenlik Stratejileri

Cilt: 16

Sayı: 35

ilişkileri ciddi şekilde sorgulamasına neden olmuştur. Taraflar arasında 1950'lerin ilk yıllarındaki güven ilişkisi bir daha kurulamayacak olsa da, Haziran 1964'ten günümüze değin Türk siyaseti ABD ile ihtiyatlı bir iyimserlikle ilişkilerini sürdürmeye devam edebilmiştir.

\section{Summary}

In the Cold War, American Grand Strategy maintained its sustainability until the fighting capability of the enemy force, the moral forces on which it rests, the ideological structure and metaphysical reasons they were attached to became ineffective. The "American Lifestyle" which is the moral element of the Grand Strategy and the theory of "Containment" which is the material element, were adopted unchanged until the dissolution of the Soviet Union in 1991. The "Stability Strategy" in the second part of the pyramid, which corresponds to the National Security Documents, has undergone little change. NSC 68 and the first evolved NSC 162/2 were loyal to the Eisenhower, Kennedy and Johnson administrations. The evolution of Eisenhower's "Massive Retaliation" concept to "Flexible Response" during the Kennedy and Johnson administrations appears as a tactical change against the moves of enemy force, that called "international communism." Because of the failed Bay of Pigs Incident and the Cuban Missile Crisis, the nuclear doctrine and covert operations had come to an end Conventional and direct intervention in the new concept came to the fore with the effect of the United States' strengthening its hand in the "Second Strike" and the Soviet's approaching "the American Island" and making the nuclear doctrine non-implementation.

Soviet Approach on Latin America in the period of President Johnson caused international communism to recruit power in the Western Hemisphere. During this period, Johnson's rhetoric of "Liberal Americans" in two continents made it necessary to use local element forces against enemy. The Inter-American Peace Force, which remained as a military force in the region for another 2 years after the intervention in the Dominican Republic, is the most concrete example 
Soğuk Savaş: Amerikan Büyük Stratejisi, Johnson Doktrini ve Kıbrıs

of the motto of "common principles and common goals" in this period. In this period, the restriction of the Soviets in the region called the Inner Crescent in order to break the communist "Domino Effect" that started with the People's Republic of China in Asia Pacific gained importance. Accordingly the United States was directly involved in the Vietnam War. However, the loss of more than half a million American military presence in the region and the loss of more than 30,000 caused the Johnson Administration, which took the public opinion behind with the social state and equal rights paradigm in domestic politics, to gradually lose the public support.

The issue of democratization in Turkey in 1960's, military coup and coup attempts, in the Turkish public and political life, the strengthening of the radical left has led to tension in Turkish-American relations. In addition, in Kennedy's administration the abandonment of the "Massive Retaliation" concept, has diminished the importance of Turkey in the front line. Nevertheless, Turkey's unilateral intervention approach to the Cyprus issue has been the first serious problem of Turkish-American relations. The systematic massacres of Greek Cypriots against Turks and the desperation and indifference of the UN and Britain against this situation have been reflected in American security documents. Nevertheless Turkey's policy towards Cyprus has crashed into American Grand Strategy in the Cold War reality. The "Johnson Letter" caused Turkish political decision makers to seriously question their relationship with the Atlantic Pact. In this case, Turkish politics have maintained relations with the US with a cautious optimism since June 1964 and The relationship of trust in the early 1950's will never be established again. 


\section{2}

Güvenlik Stratejileri

Cilt: 16

Sayı: 35

\section{Kaynakça \\ Arşiv Belgeleri}

Central Intelligence Agency Reading Room (1962-1964)

Foreign Relations of the United States (FRUS), Western Europe, Volume III, 1948.

Resmî Belgeler

NSC 68, Basic National Security Policy, April 14, Washington, 1950.

NSC 162/2, Basic National Security Policy, October 30, Washington, 1953.

\section{Kitaplar}

CARO, A. Robert; The Path to Power, The Years of Lyndon Johnson, Volume 1, Vintage, New York, 1990.

DREW, S. Nelson; NSC-68: Forging The Strategy Of Containment, with Analyses by Paul H. Nitze, National Defence University Press, Washington, 1996.

FERRELL, H. Robert; Off the Record: The Private Papers of Harry S. Truman, Harper \& Row, New York, 1980.

GADDIS, John Lewis; George F. Kennan, An American Life, The Penguin Press, New York, 2011.

GADDIS, John Lewis; On Grand Strategy, The Penguin Press, New York, 2018.

GADDIS, John Lewis; Strategies of Containment: A Critical Appraisal of American National Security Policy during the Cold War, Oxford University Press, Oxford, 2005.

GÜRCAN, Fethi; Ben İhtilalciyim, (Yay-Haz) Öner Gürcan, Süvari Yayıncılık, Ankara, 2005.

HOOKER, R.D. ; The Grand Strategy of the United States, INSS Strategic Monograph, Institute for National Strategic Studies, National Defense University, National Defence University Press, Washington, 2014.

IKENBERRY, G. John; After Victory: Institutions, Strategic Restrain, and the rebuilding of Order After Major Wars, Princeton University Press, New Jersey, 2001.

MARTEL, C. William; Grand Strategy In Theory And Practice: The Need For An Effective American Foreign Policy, Cambridge University Press, New York, 2015.

MILLER, Roger G.; To Save A City, The Berlin Airlift 1948-1949, U.S. Goverment Publishing Office, Washington, 1998.

RABE, G. Stephen; The Most Dangerous Area in the World: John F. Kennedy Confronts Communist Revolution in Latin America, The University of North Carolina Press, North Carolina, 1988.

SANVER, Ahmet; Akritas'a Karşı TMT, Yayınevi yok, Lefkoşe, 2012.

SPYKMAN, Nicholas John; The Geography of the Peace, Harcourt, Brace and Company, San Diego, 1944.

STROMSETH, E. Jane; The Origins of Flexible Response: Nato's Debate over Strategy in the 1960s, Palgrave Macmillan, Basingstoke. 1988.

TORUMTAY, Necip; Orgeneral Torumtay'ın Anıları, Milliyet Yayınları, İstanbul, 1994. YEŞILBURSA, Behçet Kemal; Bağdat Paktı 1950-1959, Çev. Nur Nirven, Vakıfbank Kültür Yayınları, İstanbul, 2019. 
ZEITZ, Joshua; Building the Great Society: Inside Lyndon Johnson's White House, Penguin Books, New York, 2018.

Makaleler

DEMIR Yeşim; “Albay Talat Aydemir'in Darbe Girişimleri”, Çağdaş Türkiye Tarihi Araştırmaları Dergisi, Sayı:12, Bahar 2006, 155-171.

KARAOSMANOĞLU, Ali; "Nükleer Strateji'nin İlk On Y1lı", Ankara Üniversitesi Siyasal Bilgiler Fakültesi Dergisi, Cilt 51, Say1 1, 1996, 323-346.

KIBAROĞLU, Mustafa; "INF Krizinin Arka Planı ve Küresel Güvenliğe Etkileri", Stratejist, Kasim 2018/16, 18-29.

KIBAROĞLU, Mustafa; "Turkey and Shared Responsibilities" in Shared Responsibilities for Nuclear Disarmament: A Global Debate, American Academy of Arts and Sciences, Cambridge, 2010, 24-27.

\section{Tezler}

LEANNE M. J. Bacon, George F. Kennan's Strategy of Containment: An Assessment of Kennan's Coherence and Consistency, Department of American and Canadian Studies, Birmingham Üniversitesi, Birmingham, 2010. (Yayımlanmamış Felsefe Yüksek Lisans Tezi).

\section{İnternet Siteleri}

"A Decade of American Foreign Policy 1941-1949, Vandenberg Resolution, Senate Resolution 239, Eightieth Congress", http://avalon.law.yale.edu/20th_century/ decad040.asp (Erişim Tarihi: 04.01.2018).

"FRUS, 1964-1968, Volume XXXII, Dominican Republic; Cuba; Haiti; Guyana", https://2001-2009.state.gov/r/pa/ho/frus/johnsonlb/xxxii/44733.htm (Erişim Tarihi: 17.01.2019).

“George Kennan's 'Long Telegram', 22 February 1946”, https://digitalarchive. wilsoncenter.org/document/116178.pdf (Erişim Tarihi: 19.01.2019).

"Inaugural Address, 20 January 1961", https://www.jfklibrary.org/learn/aboutjfk/historic-speeches/inaugural-address (Erişim Tarihi: 16.01.2019).

"Inter-American Peace Force, Public Affairs Office, Santo Domingo, Dominican Republic, 1966," https:/history.army.mil/html/bookshelves/resmat/dom_republic/ IAPF_Stability_Ops_Rpt.pdf(Erişim Tarihi: 19.01.2019).

"Johnson Letter", https://tr.scribd.com/document/38718043/Johnson-Letter (Erişim Tarihi: 19.01.2019).

"Kennedy's Foreign Policy", https:/history.state.gov/departmenthistory/shorthistory/jfk-foreignpolicy (Erişim Tarihi: 15.01.2019).

"LBJ: Biography", http://www.lbjlibrary.org/lyndon-baines-johnson/lbj-biography/ (Erişim Tarihi: 20.01.2019).

"Lyndon B. Johnson and The Vietnam War", https://prde.upress.virginia.edu/ content/Vietnam (Erişim Tarihi: 19.01.2019).

"Lyndon B. Johnson", https://www.whitehouse.gov/about-the-white-house/presidents/ lyndon-b-johnson/ (Erişim Tarihi: 20.01.2019).

"Lyndon B. Johnson, Published Text of Speech on the Domincan Republic Intervention, 2 May1965", (The Johnson Doctrine Speech), https://loveman.sdsu.edu/ 
634

Güvenlik

Stratejileri

Cilt: 16

Sayı: 35
docs/1965JohnsonDoctrine.pdf (Erişim Tarihi: 20.01.2019).

"Memorandum of Telephone Conversation, Gorbachev-Bush, 25 December 1991, Last phone call", https://nsarchive.gwu.edu/dc.html?doc=3247156-4-Memorandum-ofTelephone-Conversation-Gorbachev (Erişim Tarihi: 20.01.2019).

"Miller, Roger G.; To Save A City, The Berlin Airlift 1948-1949, U.S. Goverment Publishing Office, Washington, 1998", https://media.defense.gov/2010/Oct/01/ 2001329741/-1/-1/0/AFD-101001-053.pdf(Erişim Tarihi: 18.01.2018).

"President Kennedy's Special Message To The Congress On Urgent National Needs,, 25 May 1961", https:/www.jfklibrary.org/archives/other-resources/john-f-kennedy-speeches/ united-states-congress-special-message-19610525 (Erişim Tarihi: 16.01.2019).

"President Truman's Special message to the Congress on Greece and Turkey: The Truman Doctrine, 12 March 1947", https://www.trumanlibrary.gov/soundrecordingrecords/sr64-47-president-trumans-special-message-congress-greece-and-turkeytruman (Erişim Tarihi: 19.01.2019).

"Telephone conversation \# 1644, sound recording, Lyndon B. Johnson and Robert Mcnamara, 29 January 1964, 6:32 PM", https://www.discoverlbj.org/item/tel-01644 (Erişim Tarihi: 19.01.2019) "Telephone conversation \# 2305, sound recording, Lyndon B. Johnson and Dean Rusk, 2 March 1964, 11:35 AM", https://www.discoverlbj.org/item/tel-02305 (Erişim Tarihi: 19.01.2019).

"The President's Address to the Nation Announcing Steps To Limit the War in Vietnam and Reporting His Decision Not To Seek Reelection, 31 March 1968", http://www.lbjlibrary.net/collections/selected-speeches/1968-january-1969/03-311968.html (Erişim Tarihi: 17.07.2019).

"The Sources of Soviet Conduct by 'X' (George F. Kennan) July 1947", https://www.foreignaffairs.com/articles/russian-federation/1947-07-01/sources-sovietconduct (Erişim Tarihi: 15.02.2019). 